DOI: https://doi.org/10.32653/CH163770-796

Magomedhan M. Magomedhanov, D.Sc. (in History), Prof., Head of Dept. of Ethnography, The Institute of History, Archaeology and Ethnography Dagestan Federal Research Centre of RAS, Makhachkala, Russia mkhan@yandex.ru

Robert Chenciner, Honorary Researcher, Prof., St. Antony's College, University of Oxford, United Kingdom chenciner@clara.net

Marian Chenciner, Honorary Researcher, St. Antony's College, University of Oxford, United Kingdom chenciner@clara.net

Maysarat K. Musaeva, Ph.D. (in History) Leading Researcher The Institute of History, Archaeology and Ethnography Dagestan Federal Research Centre of RAS, Makhachkala, Russia majsarat@yandex.ru

Saida M. Garunova, Junior Researcher, G. Tsadasa Institute of Language, Literature and Art Dagestan Federal Research Centre of RAS, Makhachkala, Russia saida-mag@yandex.ru

\title{
DAGESTAN. MOUNTAIN-VALLEY HORTICULTURE: DEFINING AGRICULTURE, HORTICULTURE AND GARDENING
}

(C) M.M. Magomedhanov, R. Chenciner, M. Chenciner, M.K. Musaeva, S.M. Garunova, 2020

(C) Daghestan Federal Research Centre of RAS, 2020

(@) $(1)$ Creative Commons Attribution 4.0 International License 
DOI: https://doi.org/10.32653/CH163770-796

Магомедханов М.М., д.и.н., заведующий отделом этнографии Институт истории, археологии и этнографии Дагестанский федеральный исследовательский центр РАН, Махачкала, Россия mkhan@yandex.ru

Роберт Ченсинер, почетный научный сотрудник, проф.

Колледж Св. Антония, Оксфордский университет, Великобритания chenciner@clara.net

Мариан Ченсинер, почетный научный сотрудник, Колледж Св. Антония, Оксфордский университет, Великобритания chenciner@clara.net

Мусаева Майсарат Камиловна к.и.н., ведущий научный сотрудник Институт истории, археологии и этнографии Дагестанский федеральный исследовательский центр РАН, Махачкала, Россия majsarat@yandex.ru

Гарунова C.M., младший научный сотрудник Институт языка, литературы и искусства им. Г. Цадасы Дагестанский федеральный исследовательский центр РАН, Махачкала, Россия saida-mag@yandex.ru

\section{ДАГЕСТАН. ГОРНО-ДОЛИННОЕ САДОВОДСТВО: ДЕФИНИЦИИ «АГРОКУЛЬТУРА», «ХОРТИКУЛЬТУРА», «САДОВОДСТВО»}

(C) Магомедханов М.M., Ченсинер Р., Ченсинер М., Мусаева М.К., Гарунова С.М., 2020

(C) Daghestan Federal Research Centre of RAS, 2020

@) Creative Commons Attribution 4.0 International License 
Abstract. The article is devoted to the historical and ethnographic description of mountain gardening in Dagestan. A brief overview of the definitions of agriculture, horticulture and gardening is given. The importance of avoiding confusion between these basically close and partly identical terms in anthropological and ethnographic studies is illustrated in the case of mountain-valley horticulture. This approach examines a) the symbiosis of the economic and cultural traditions of the region; b) components of ethno-economics and ethno-ecology; c) technological modernization of the agricultural industry; d) an indicator of the resource potential of sustainable development of mountainous areas, the population of which retains traditional economic specialization; e) economic integration of mountainous territories into the region, the country, and the formation of interregional ties that give stability to the ethnic economy; f) criteria for the appropriate preservation of traditional ethno-culture.

The multiethnic composition of the population of the Russian Federation, different geographic conditions and socio-economic levels of development of its regions predetermine the relevance of the development of projects and programs for sustainable development of territories adapted to specific historical and cultural areas, the use of recreational potentials, ethnic identity as "brands" with the obligatory consideration of probable, often negative consequences.

In this regard, the social problems associated with the need to preserve the historical, cultural and natural heritage, traditional life support systems, and the economic specialization of mountain areas are considered. The importance of craft centers that continue to preserve the traditions of Russian "brands", create authentic, ethnographically colorful "regional" products is emphasized. It is noted that since the 1990s, mountain-valley gardening in Dagestan has been in a state of stagnation due to socio-political, legal (land use and land use) and demographic (depopulation of mountainous territories) factors.

Keywords: Dagestan; mountain valleys; ethnoeconomics; ethnoecology; agriculture; horticulture; mountain-valley gardening.

Аннотация. Статья посвящена историко-этнографическому описанию горного садоводства в Дагестане. Приведен краткий обзор определений "agriculture", "horticulture", "gardening". Отмечена важность избегания путаницы между этими, в основном близкими и, отчасти, идентичными терминами в антропологических и этнографических исследованиях горно-долинного садоводства, рассматриваемого как: а) симбиоз экономических и культурных традиций региона; б) компонент этно-экономики и этно-экологии; в) технологическая модернизация агропромышленного комплекса; г) показатель ресурсного потенциала устойчивого развития горных территорий, население которых сохраняет традиционную экономическую специализацию; д) экономическая интеграция горных территорий в регион, страну и формирование межрегиональных связей, придающих стабильность национальной экономике; е) критерии надлежащего сохранения традиционной этнокультуры. Подобные исследовательские подходы позволяет высветить проблемы не только на Кавказе, но и в отличающихся по уровню социально-экономического развития многонациональных регионах страны, многие из которых ошибочно видят устойчивое развитие в рекреационном потенциале территории и использовании этнической самобытности как «бренда», не учитывая потенциальных, а зачастую и негативных последствий. В этой связи обращено внимание на выявлении социальных проблем, связанных с необходимостью сохранения исторического, культурного и природного наследия традиционных систем жизнеобеспечения, экономической специализации, на развитии ремесленных центров, сохраняющих традиции российских «брендов» и аутентичность региональных продуктов, а также на то, что с 1990-х годов горно-долинное садоводство в Дагестане находится в состоянии стагнации из-за социально-политических, правовых (землепользование и землепользование) и демографических (депопуляция горных территорий) факторов.

Ключевые слова: Дагестан; горные долины; этноэкономика; этноэкология; агрокультура; хортикультура; горно-долинное садоводство. 


\section{Market economy and decline in agricultural production}

The transition to a market economy has led to a decline in agricultural production. Since the 1990s, in Dagestan, as in several other regions of the Caucasus, mountainvalley horticulture has been in a terminal state. Field data that we collected during our ethnographic expedition in 2019 to the areas of the traditional distribution of Mountain-valley Gardening (Gergebilsky, Khunzakhsky, Botlikhsky districts) allowed us to examine the structure and function of land areas, the technology of constructing artificial terraces for orchards and vineyards, irrigation systems, the locally ordered processes of irrigation and deciding on garden boundaries.

Currently, there is a real threat of irretrievable disappearance of local varieties. This is due to the privatization of land, the reconstruction of ancient gardens, and the flooding of areas of mountain-valley gardening. They are much larger in Dagestan than anywhere else because of the water basins/artificial lakes at hydroelectric power stations.

The poor support of the government has aggravated an already difficult situation in this industry. As a result, by the year of 2000, the area of orchards was reduced to 22.1 thousand hectares, and fruit production to 45.3 thousand tons. The nursery base practically ceased to exist, and the canning industry enterprises were left without raw materials and stopped functioning and/or were mothballed, as a result of which the economy of the republic suffered significant damage and people were left without work. The restoration of these canneries on an old obsolete and economically disadvantageous technological basis is futile. Gardens in the mountain valleys are in disrepair, the main areas are unproductive. Even branded fruit varieties such as Arakan Red, Golotlinsky, Dzhir-Haji, Kakhar-ich, Renet Akhtynsky, Dakur Chukhver, and Kal Chukhver have practically disappeared.

Dagestan possesses all necessary conditions for growing and processing a wide range of fruits and berries, providing both the domestic market and processing enterprises, but it must be recognized that the existing potential is not used effectively. Previously, the Dagestan market was saturated exclusively with local products, and today, as we know, the Dagestan consumer uses imported products of dubious origin. There are more imported products in our markets than our own.

However, government measures to protect the population from low-quality imports are not applied. Fruit and berry products are imported from Moldova, Azerbaijan, Iran, Morocco, Israel, Argentina, Brazil and Egypt. As background, the opportunity and conditions to develop local production are neglected, bearing in mind that local products are not inferior to imports in taste and sometimes even significantly superior in environmental characteristics. High potential yields, winter hardiness, profitability, the possibility of fresh and processed sales are the main advantages of Dagestan varieties. Development is further hindered by bans from Russia's Federal Veterinary and Phytosanitary Oversight Service (Rosselkhoznadzor) on importing seeds, cuttings, and trees to Russian Federation for various given reasons such as 
pests and avoidance of GM plants. For example, in April 2013 there was a temporary ban on seed-potato imports from the EU affecting 21,000 tons of seed potatoes annually exported by EU member states to Russia, due to alleged pest risk.

The following reveals this unfortunate state of affairs and proposes possible solutions.

\section{Essential Irrigation}

Mountainous gardening is an ancient and traditional branch of the economy of the Highland Dagestan. Terracing slopes is one of the most ancient, large-scale and powerful forms of anthropogenic engineering, surpassing all other forms of human impact on the earth's landscape, including roads and cities. Terracing of mountain slopes to enlarge the conservation and accumulation of soil, moisture, and thus increase yields, is recognized as one of the greatest achievements of the Ancient World, along with the domestication of plants and animals. "A person changed a mountain, but in return, it also changed the consciousness of the mountaineer. It changed society itself, that had created this culture" [1, p. 30]. Dagestan is part of the zone from where it is believed terrace culture spread across the globe, making it one of the oldest original centers of terrace farming. Archaeological data consisting of findings of fruit seeds in the Irganai and Chirkei settlements of the Bronze Age (II millennium BCE) suggest how early the inhabitants of mountain-valley settlements were engaged in horticulture.

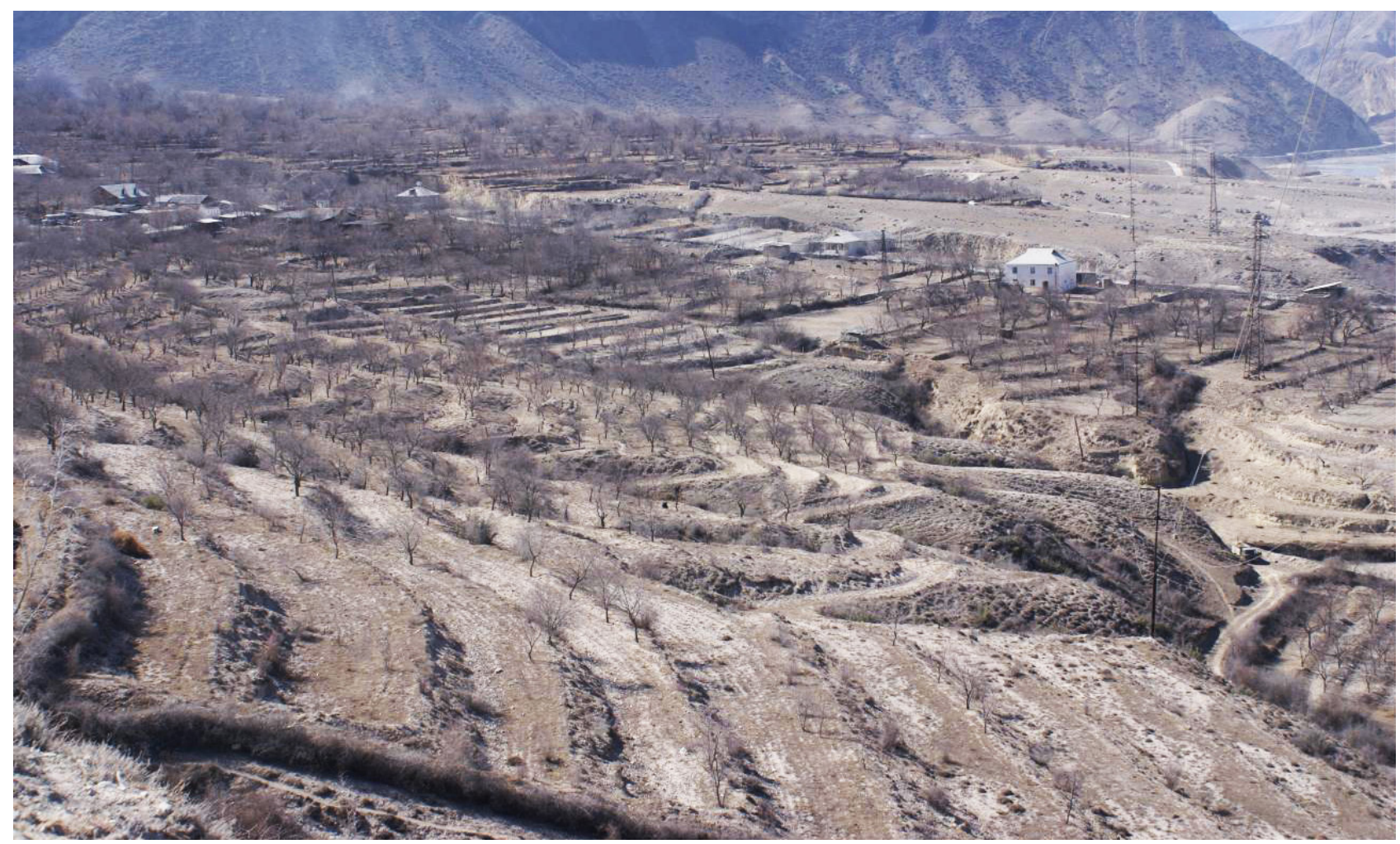

Fig. 1. Garden terraces, Igali village. Photo by M.A. Aglarova, 2005

Рис. 1. Садовые террасы, сел. Игали. Фото М.А. Агларова, 2005 г. 


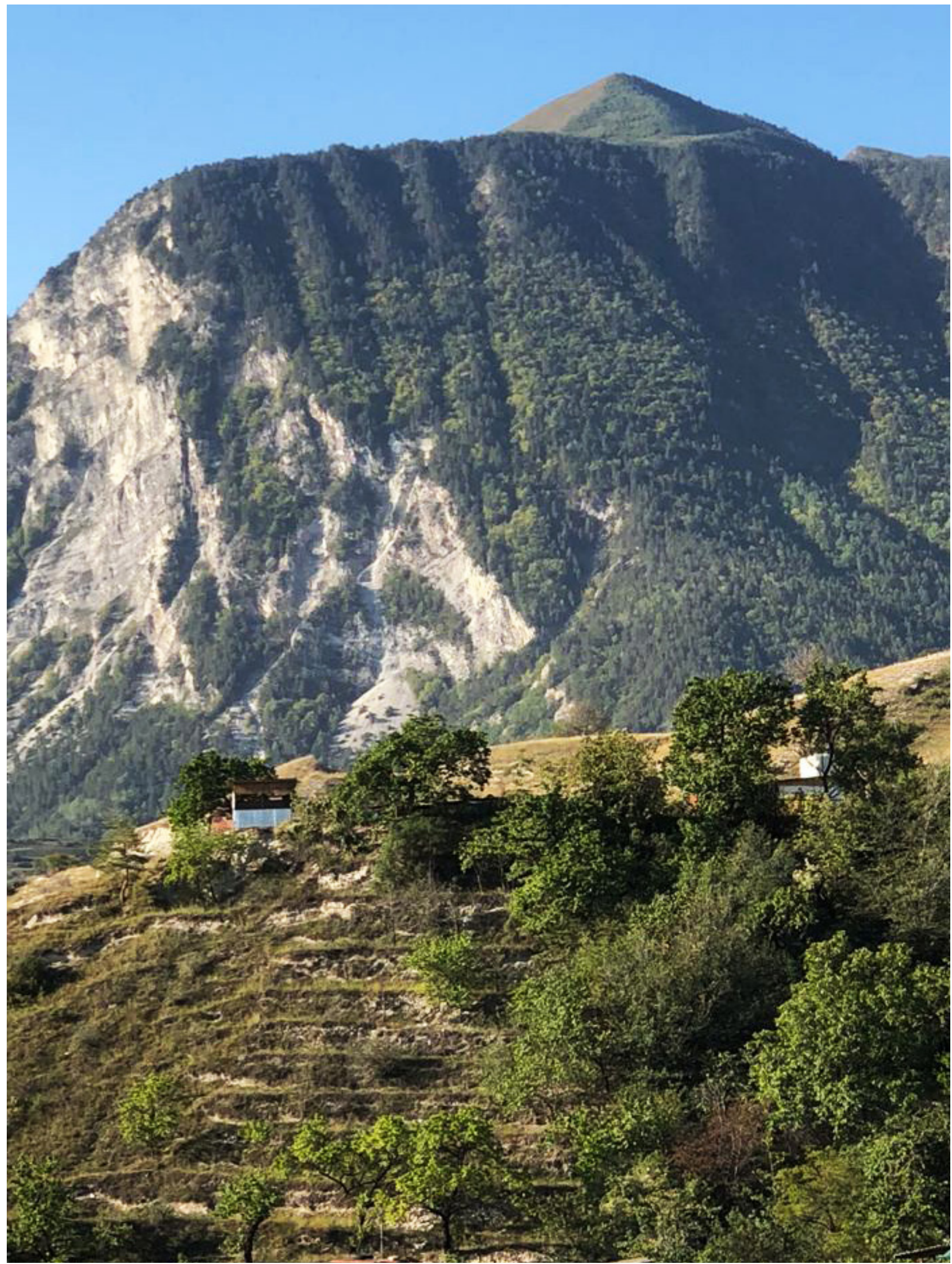

Fig. 2. Garden terraces, Untsukul village. Photo by M. Gadzhidadaev, 2020

Рис. 2. Садовые террасы, сел. Унцукуль. Фото Гаджидадаева М., 2020 г. 


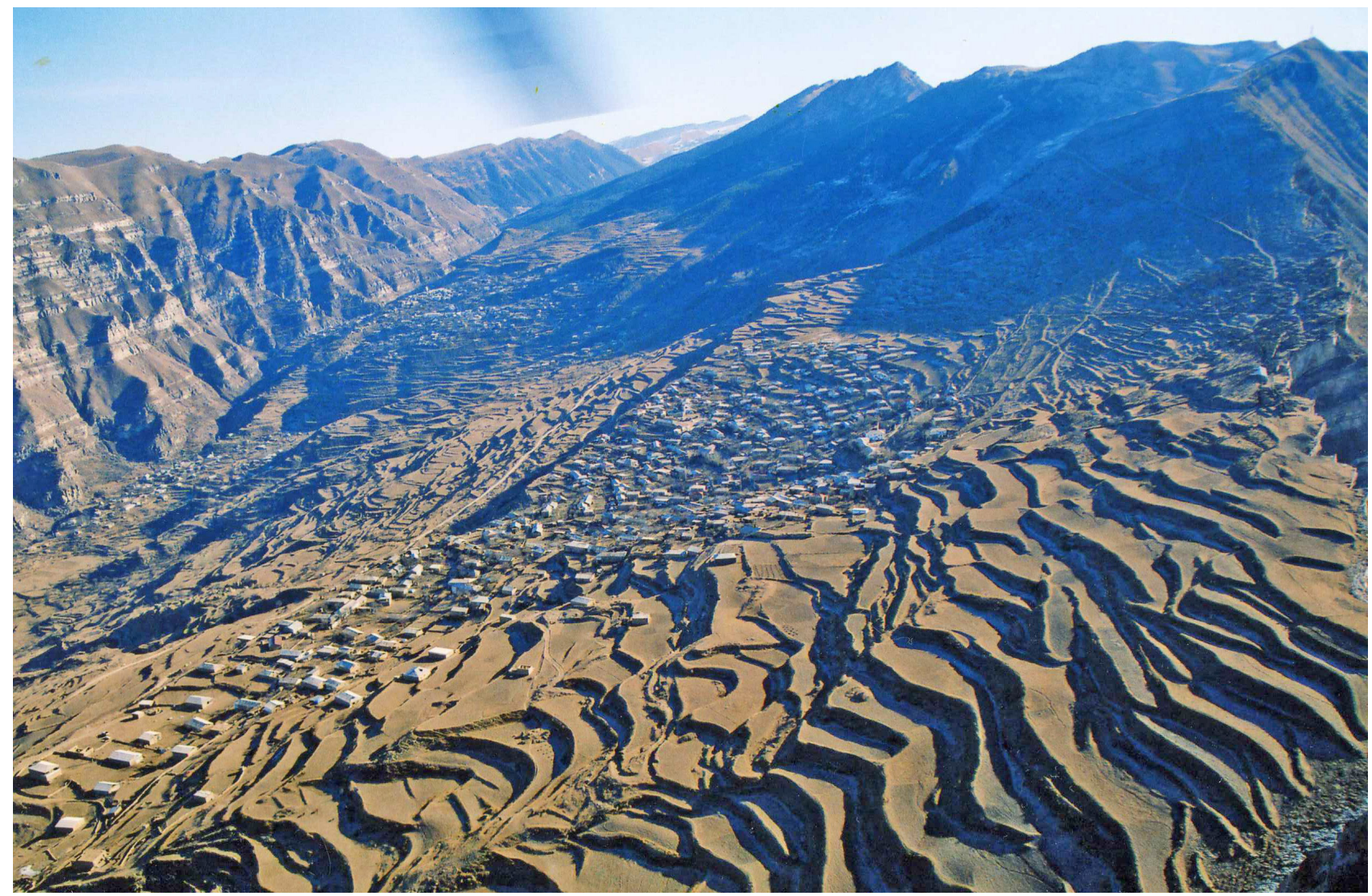

Fig. 3. Terraced fields between the villages of Kahib and Goor. Photo by M.M. Magomedkhanov, 2017

Рис. 3. Террасированные поля между селами Кахиб и Гоор. Фото Магомедханова М.М., 2017 г.

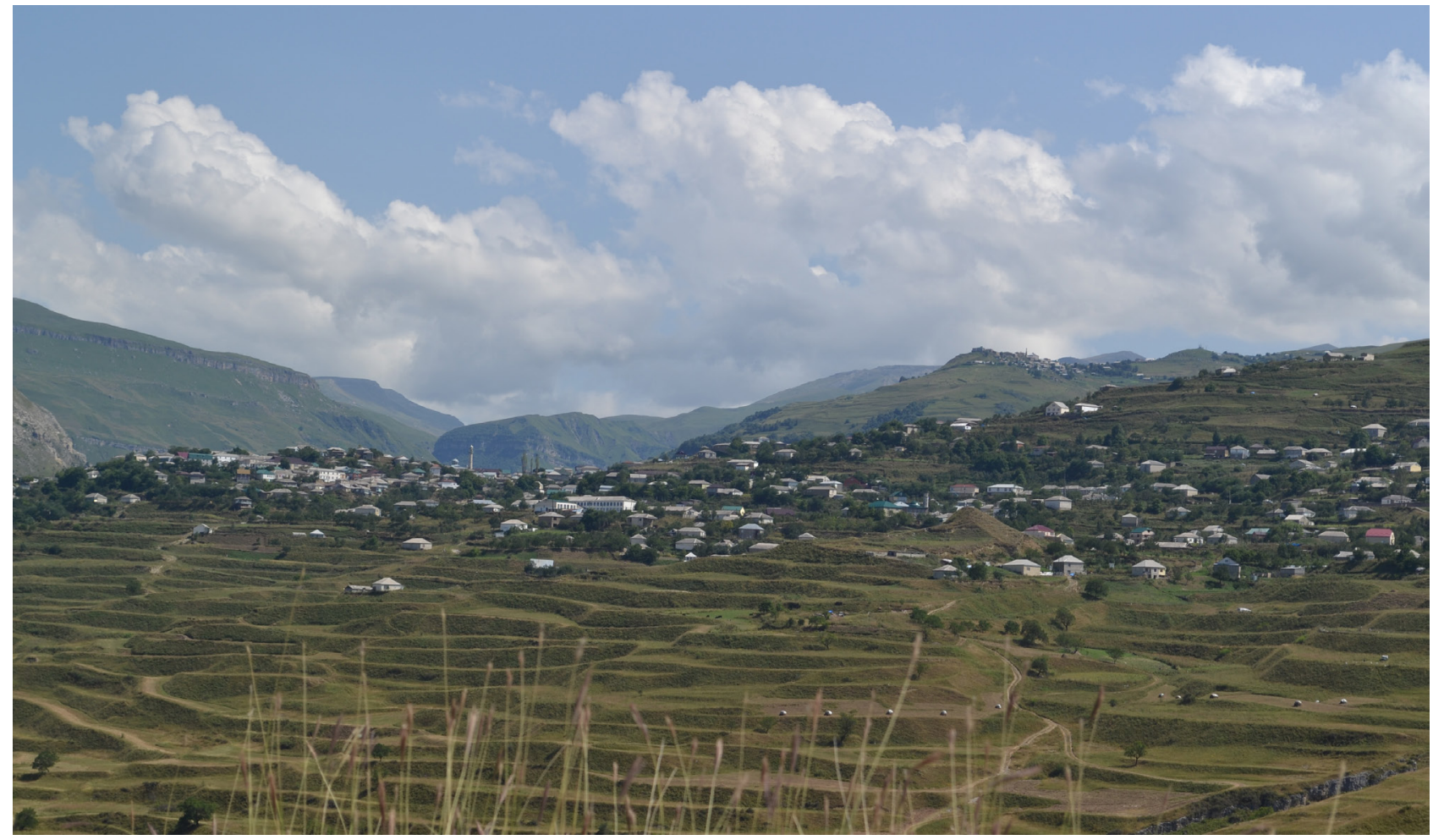

Fig. 4. Terraced fields, Karata village. Photo by M.M. Magomedkhanov, 2017

Рис. 4. Террасные поля, сел. Карата. Фото М.М. Магомедханова. 2017 г. 


\section{Terracing from Antiquity}

Since the Bronze Age, thanks to the warm mild climate and the possibility of artificial irrigation in the mountain river valleys, [1] horticulture developed in all the varieties of fruit plant species. Almost all the most important cultivars of fruit trees were cultivated in the gardens of Dagestan: Caucasian persimmons, peaches, apricots, pears, apples, cherries, plums, walnuts, almonds and others. Many valuable varieties of garden crops grew here, most of which unfortunately have disappeared without a trace. According to the reports of our informants during expeditions to the mountain-valley territories of Dagestan, as well as Dr Magomed Abdulgamidovich Magomedov and other scientists from the Institute of "Mountain Botanical Garden", most local varieties were more resistant to diseases and pests than imported ones. The fruits were distinguished by good taste, marketability, large (nowadays uniform) size, and good transportability and storage, even under adverse conditions. The natural and climatic conditions of Mountain Dagestan form unique conditions for growing apricots and peaches that are unmatched in taste and are in high demand in both domestic and outside markets.

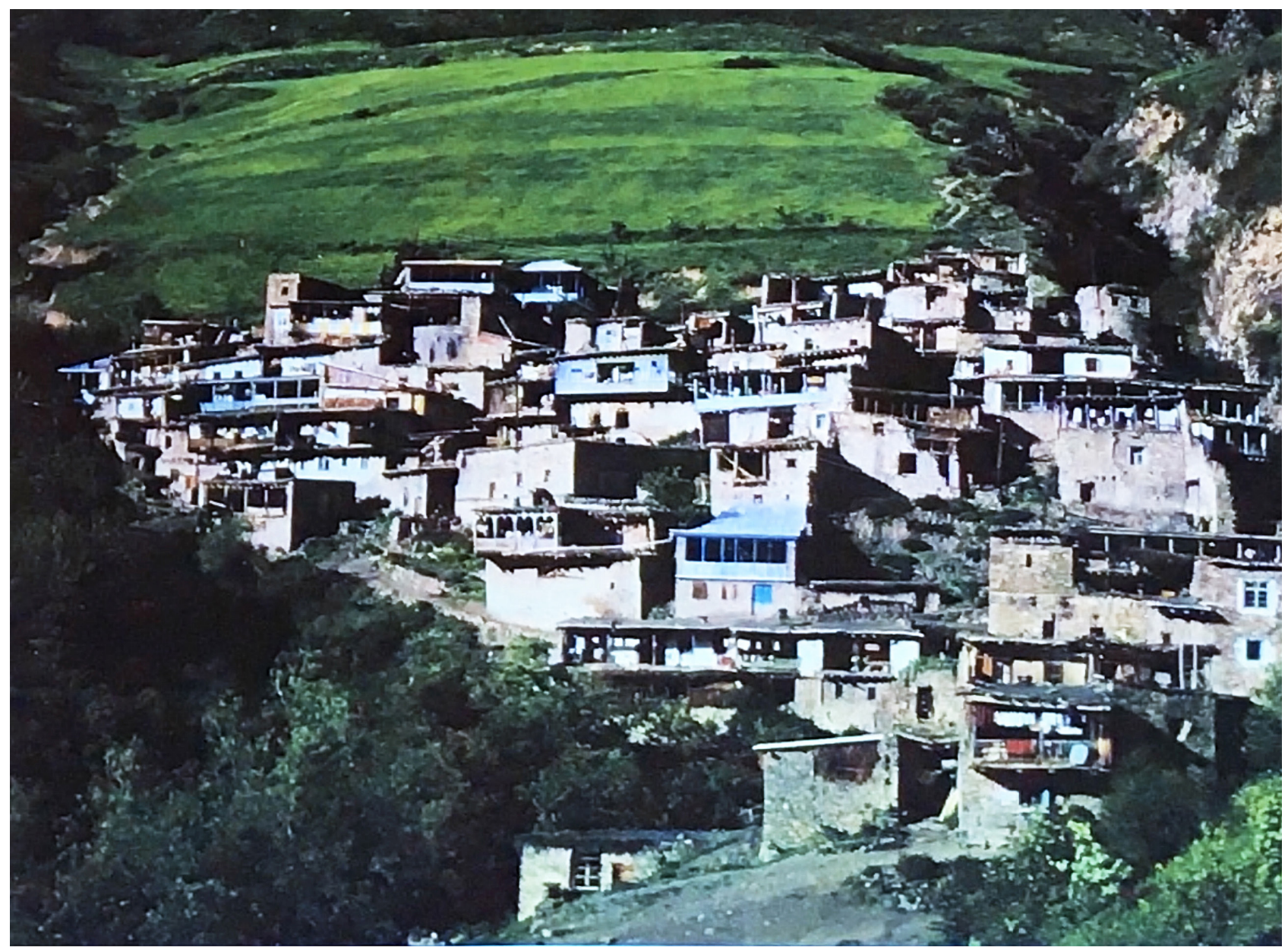

Fig. 5. The village of Rugelda, the "capital" of the Keleb community // Movchan G.Y. Old Avar dwelling. M., 2001: 179

Рис. 5. Селение Ругельда, «столица» общества Келеб // Мовчан Г.Ю. Старый аварский дом. М., 2001. С. 179 


\section{Importance of Horticulture}

In many villages located in the mountain valleys, horticulture was the main branch of agriculture.

Although almost everywhere in Dagestan, the cultivation of grain and the production of meat was of major importance, some mountain communities specialized exclusively in one type of production (later known as ethno-economy), for example, salt mining (in the village of Kwanhidatl), fruit growing (Botlikh), the production of edged weapons and firearms (Harbuk), forging steel (Amuzgi), jewelry (Kubachi), etc. In the economy of Dagestan, gardening occupied a very important, but still not the first place in the traditional ethno-economy (In Dagestan there are 31 indigenous ethnic groups and while some villages have said four ethnic quarters many villages and districts are mono-ethnic and have their own specialties, for example, Archi are known as shepherds and Dargin Levashi grew cabbages for Russian market.

Farm gardening, called cottage gardening in England from perhaps XV century, was a rational activity for the population in terms of its high productivity. Horticultural products were exchanged for grain and livestock products in both the plains and high mountains of Dagestan, which ensured economic stability in these areas [2; 3].

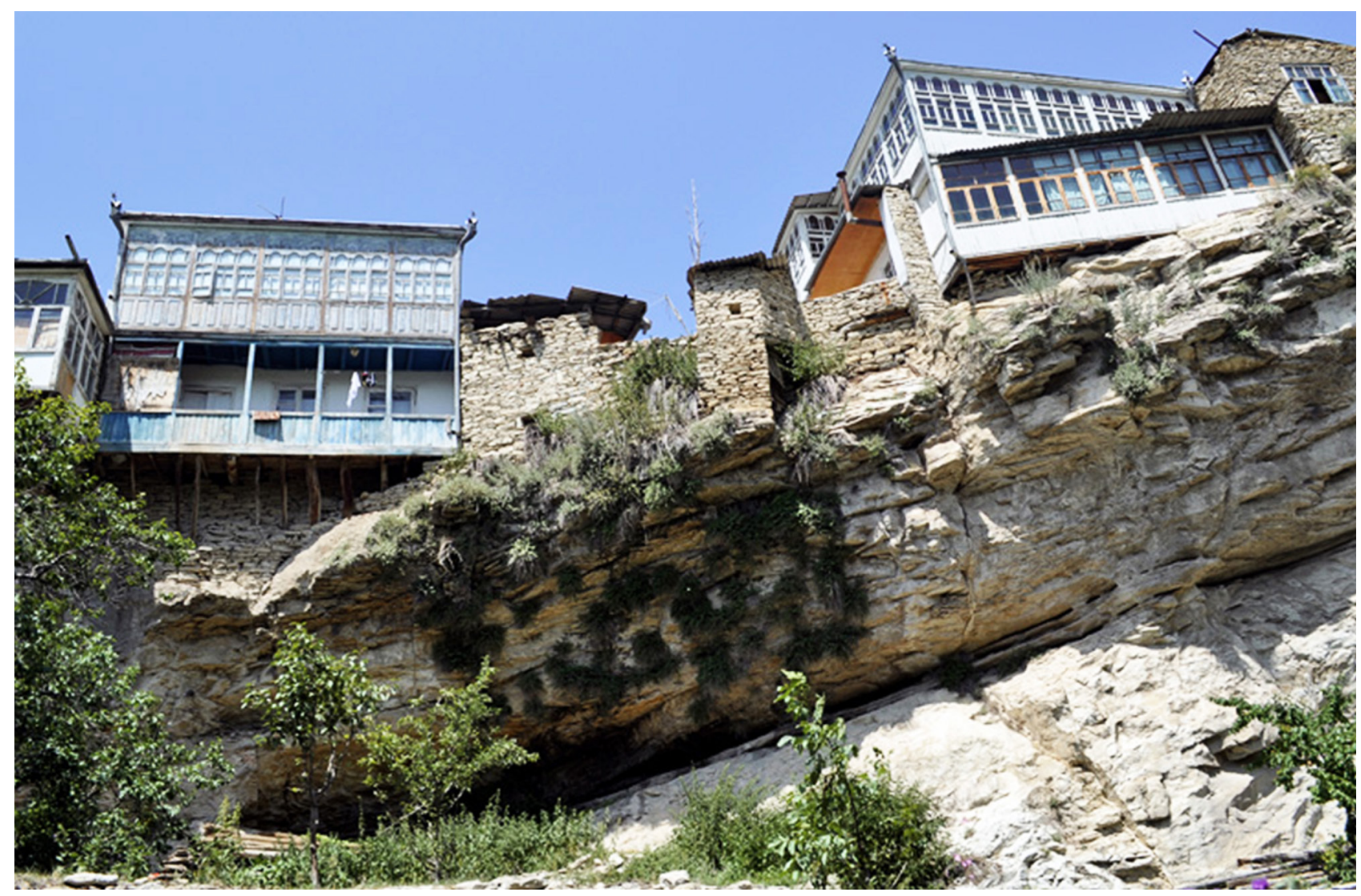

Fig. 6. Saving fertile land as the basic principle of the settlement culture of the peoples of Dagestan. Mekegi village. Photo from the personal archive of M.K. Musaeva, 2014

Рис. 6. Экономия плодородной земли - основной принцип поселенческой культуры народов Дагестана. Сел. Мекеги. Фото из личного архива Мусаевой М.К., 2014 г. 


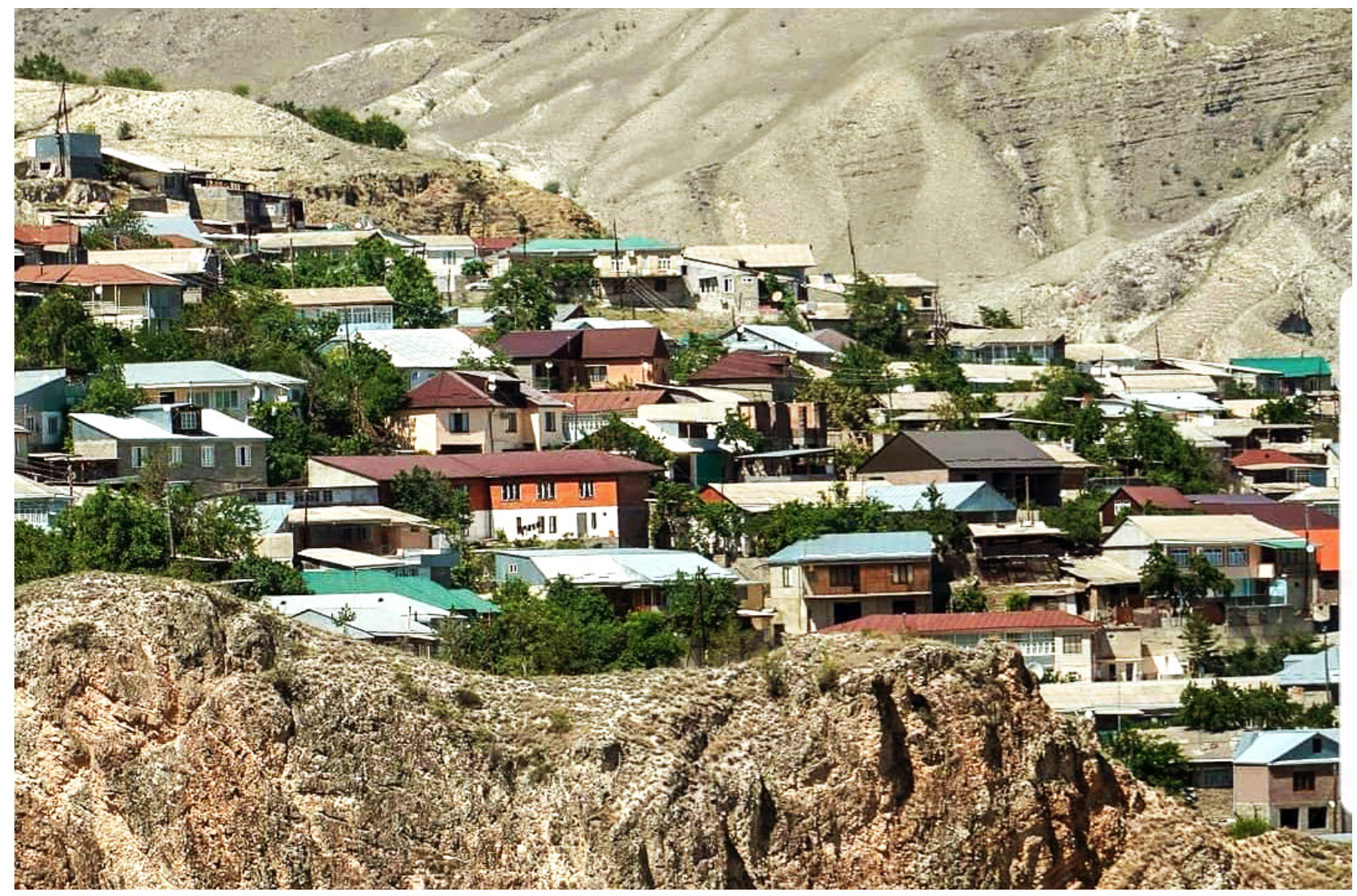

Fig. 7. Saving fertile land // Gadzhidadaev M. "Untsukul vicinity", 2020

7. Экономия плодородной земли // Гаджидадаев М. «Окрестности Унцукуля», 2020 г.

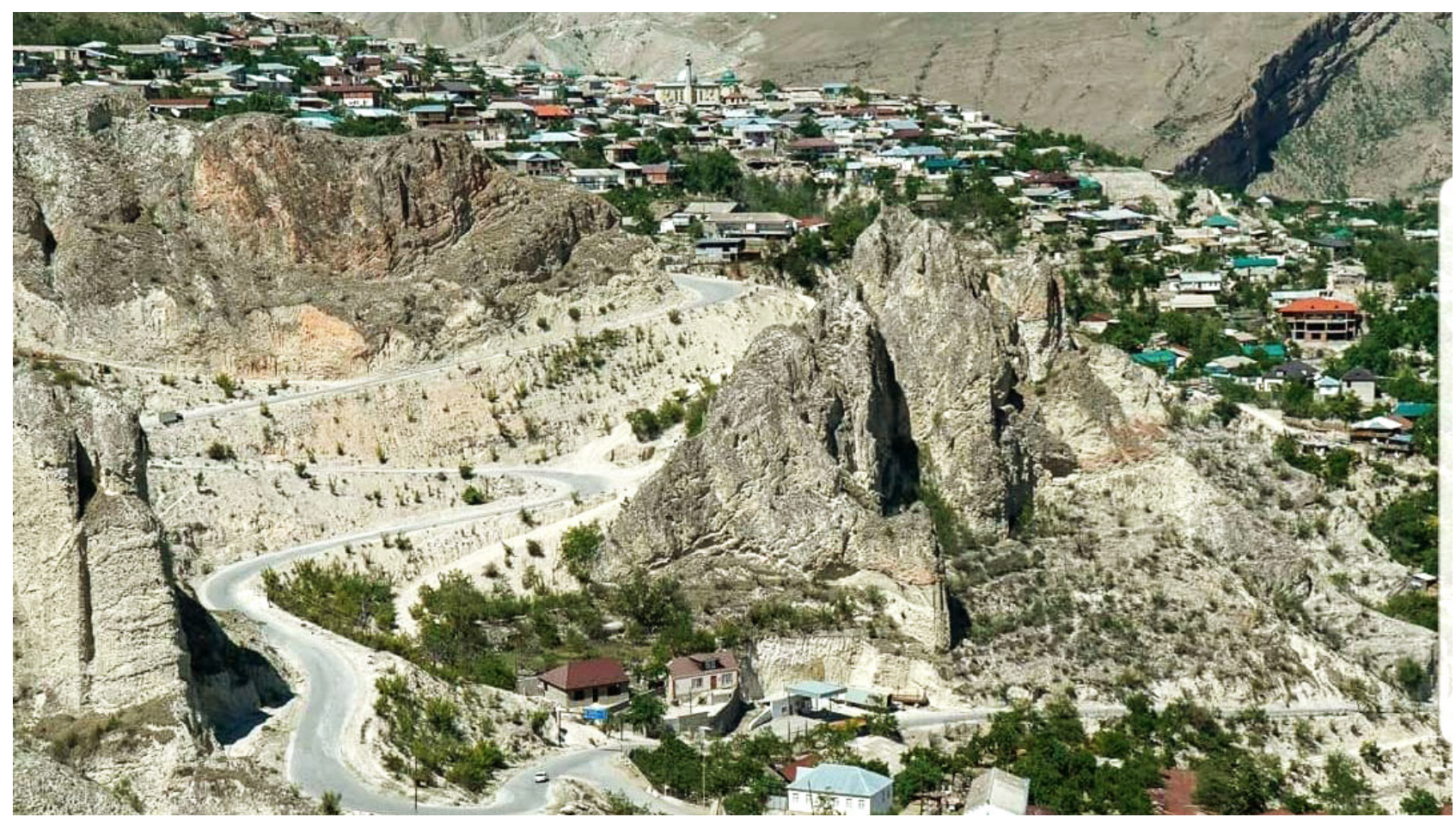

Fig. 8. Saving fertile land // Gadzhidadaev M. "Untsukul vicinity", 2020

Рис. 8. Экономия плодородной земли // Гаджидадаев М. «Окрестности Унцукуля», 2020 г. 
Bringing the fruit harvest to market was a tricky business. Over long distances, only dried fruits, nuts, and apricot kernels could be exported. Fresh, delicate fruits such as apricots, peaches, and cherries could not be transported over long distances, especially on horse-drawn or pack transport at least till the end of the XIX century when the Russian railway line arrived in Dagestan.

It is noteworthy that in all feudal societies of Dagestan, fruits were included in the list of taxes to feudal lords. The Ummah Khan of Avar taxed his subject villages specifically in gardening products, and other villages with developed cattle breeding paid their tax in livestock products.

\section{Regulation}

The mountain-valley jamaats (local councils) paid attention to the regulation of economic activities, including horticulture and winemaking. From adat customary law records (XVI-XVII centuries), harsh penalties were provided for violating the established order, "a ban on eating grapes,"

In the Dagestan adats, punishment involved material payment-in-kind by land, cattle, copper boilers, textiles, but never by fruits and vegetables. It was possible to pay financial fines in say gold or silver instead, but in-kind was more visible. However, any attempt to spoil the arable field and, moreover, the garden, fruit trees were punished severely. In particular, the adats of the Tindal naibstvo of the Khvarshin community contain the following items: "Chapter XII. On cutting down a tree from someone else's property, mulk.

$\S 1$. If a fruit tree is cut down, the perpetrator pays a fine of 50 kopecks in favor of the village and the tree value to its owner. If it is a non-fruit tree, then he pays half of the fine, that is, 25 kopecks." In the adats of the Karata community, the punishment is the same, but the amount of the fine is higher: "Chapter 11. On cutting down trees of fruit and private forests. $\S 1$. For cutting down a fruit tree, the guilty person pays the victim the cost of it or returns the same tree to him and pays a fine in favor of the community in the amount of 1 ruble." [4, p. 132; p. 150]. Thus, according to the adat of the village of Kudutl, "if someone cuts off an apricot tree, take a measure of grain." Setting fire to a field with a harvest, a hayloft, stacks of straw, a garden at any time of the year, as well as setting fire to a house, destroying a bridge and killing an innocent person in Dagestani adats were equated with terror, and those guilty of this were terrorists with all the most severe consequences. Fruit picking, according to custom, was required to start at the same time on a certain day. Violation of the rules was punishable by a severe fine.

\section{Development since the 1860 s}

With the accession of Dagestan to Russia and the establishment of reliable trade and economic ties, horticulture began to develop rapidly and became the second most important branch of the economy of Mountain Dagestan after cattle breeding. 


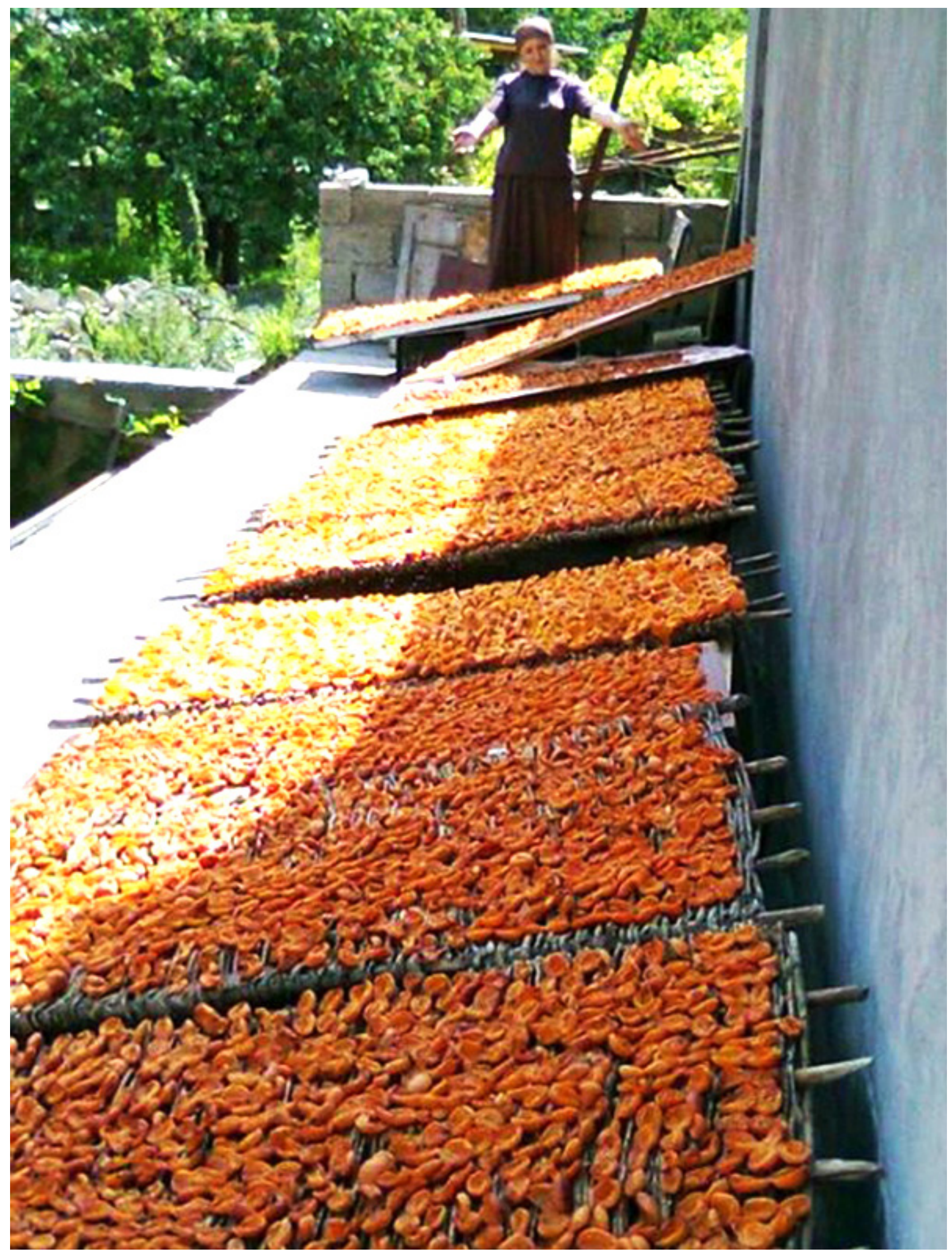

Fig. 9. Apricots drying. Miarso village, Botlikh district. Photo by M.M. Magomedkhanov, 2016

Рис. 9. Сушка абрикосов. Сел. Миарсо, Ботлихский район. Фото Магомедханова М.М., 2016 г. 
The first decades of the twentieth century were especially favourable for the horticultural economy.

As M.M. Yakhyaev, the economic historian, noted: "The area of gardens in Dagestan has increased many times over. According to existing data, over 14 years (from 1900 to 1914) in the Darginsky district, which included the villages of Khadzhalmakhi and Tsudakhar, the area under garden cultivation increased 5.15 times, in Avar - 3.83 times, in the Andean - 4.55 times, in Gunib - 17 times.

At one of Temir-Khan-Shura's (then the capital, now Buinaksk) factories for the production of vegetable and fruit purees and canned fruit, owned by Khizri Hajiyev in 1902, 20 thousand poods of canned food and 18 thousand poods of mashed apricots and plums were produced. He also had two more factories, one in the village of Arakani in the Avar district and the other in the Khadzhalmakhi of the Dargin district. These factories gave 800 poods of canned puree to the amount of about 50 thousand rubles. Already in 1914, 45 small handicraft factories were founded in the Hindalal, which produced up to 500 tons of products. In pre-revolutionary Dagestan, the number of dried fruits reached 980 tons (dried fruits - first of all, we mean dried apricot-dried apricots 50\% and 15\% plums). "Products exported from Dagestan, especially dried fruits, canned food, mashed potatoes, ended up in the Nizhny Novgorod province, from there to Manchuria, China, where they successfully competed with canned food produced in California" [5, p. 17].

In comparison with the area used for grain crops, gardening in Dagestan was significant. For example, in 1913, out of 208.7 thousand hectares of sowing areas, 199.75 thousand hectares, or $95.7 \%$ were grain crops. The share of industrial crops was 4.11 thousand hectares, vegetables and melons 2.14 thousand hectares and forage 2.7 thousand hectares. The area of the orchards was 4.4 thousand hectares, and a similar amount was occupied by vineyards. Judging by numerous testimonies some parts of Dagestan were covered with orchards, their main treasures. In other regions, gardening was only an auxiliary activity, and in others, it began to develop only in Soviet times, during the years of mass collectivization [6, p. 10].

\section{Climate}

One of the important factors that determined the degree and nature of the development of horticulture and the entire economic activity of the population were the climatic and geographical features of the region. Therefore, gardening was most developed on the plains in the south, Kyurinsky district, near Derbent "in the residence of large feudal lords" and in the southern foothills of the Kaitago-Tabasaran district. Especially suitable were the high plateaus of the North-Tabasaran area, about the villages of Nizhne Kaitagsky and Urkarakhsky and in the northern foothills of Temirkhan-Shurinsky district. Horticulture also developed significantly in the valleys of mountainous Dagestan: the Avar, Andy, Gunib, Samur and part of Darginsky districts [7, p. 235]. Sometimes, too, grain fields were cultivated in lowlands and higher, and gardens in the plains. 
One advantage of mountain river valleys is the hot climate and the absence of sharp fluctuations in temperature. The availability of numerous free water sources allows general use of irrigation. Thus, the mountain valleys benefited from the ancient and intensive settlement. Mountain-valley gardening had a higher level of development, in comparison with flat and foothill gardening, which was mainly of a consumer nature, because of the strong grain base. Almost all the important varieties of fruit trees were cultivated in the gardens of Dagestan: Caucasian persimmons, peaches, apricots, pears, apple trees, cherries, plums, walnuts, almonds, and cherries.

\section{Seeds and Grafting}

In the past gardening was carried out in different ways: by sowing seeds obtained from wild fruits or by replanting young trees from the forest. On the plains and foothills, the establishment of gardens was mainly due to the clearing of forest areas, where there were many wild fruits in forest gardens. At the same time, forest trees were uprooted, leaving wild fruits, which were re-grafted with cultivated varieties. Almost everywhere in Dagestan, the characteristic feature was that the grafting of wild trees was carried out at a height of 1-2 meters so that grazing cattle could not spoil the grafts and tree crowns.

Fruit trees rarely made up continuous plantations, but mostly formed small gardens in many estates, in forest glades, and near houses. Gardeners sought, as far as possible, to arrange gardens around their village, near their houses and winter pastures of livestock, by replanting wild fruits from the forest. Then cuttings of the

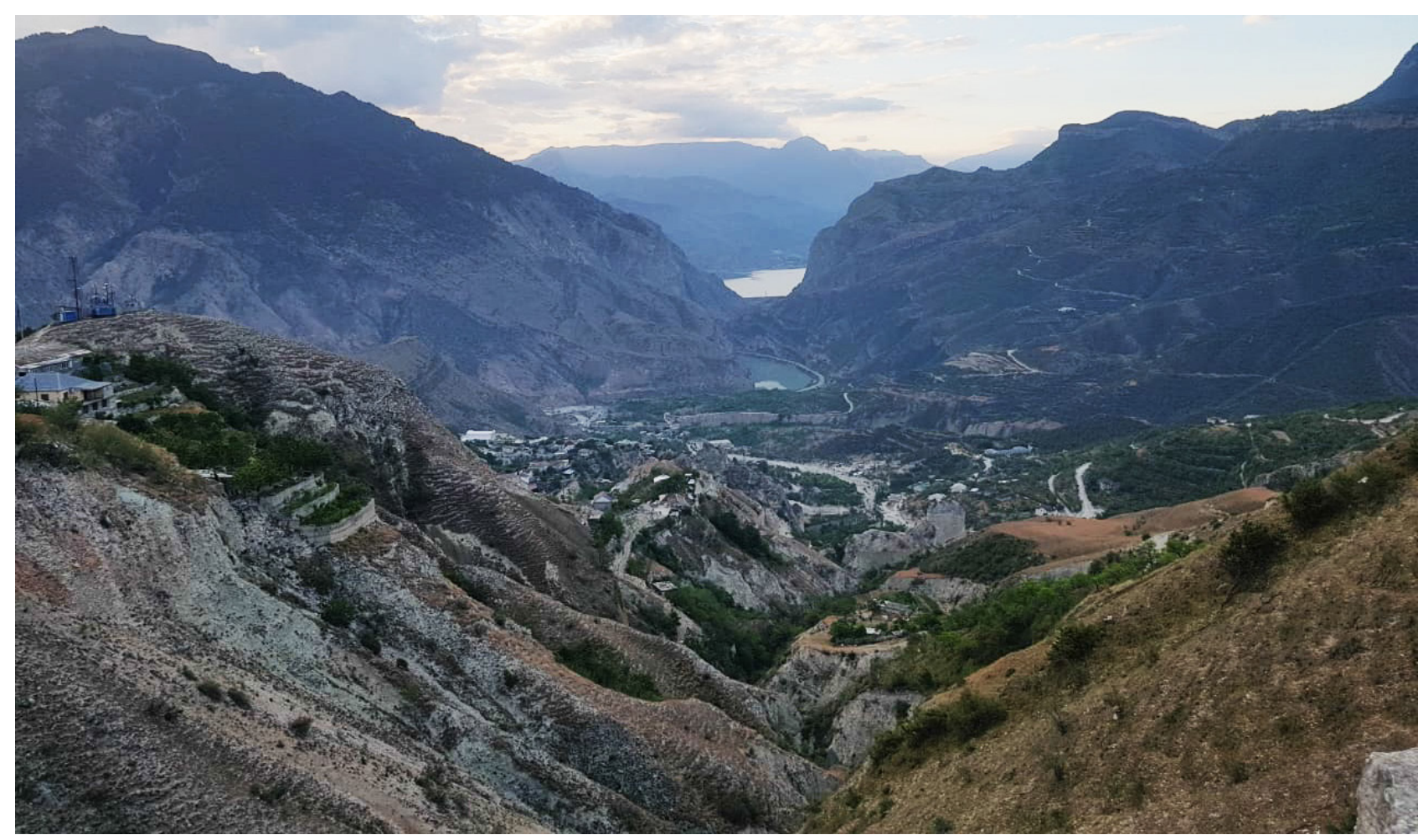

Fig. 10. Untsukul gardens // Gadzhidadaev M. "Untsukul vicinity", 2020

Рис. 10. Унцукульские сады // Гаджидадаев М. «Окрестности Унцукуля», 2020 г. 


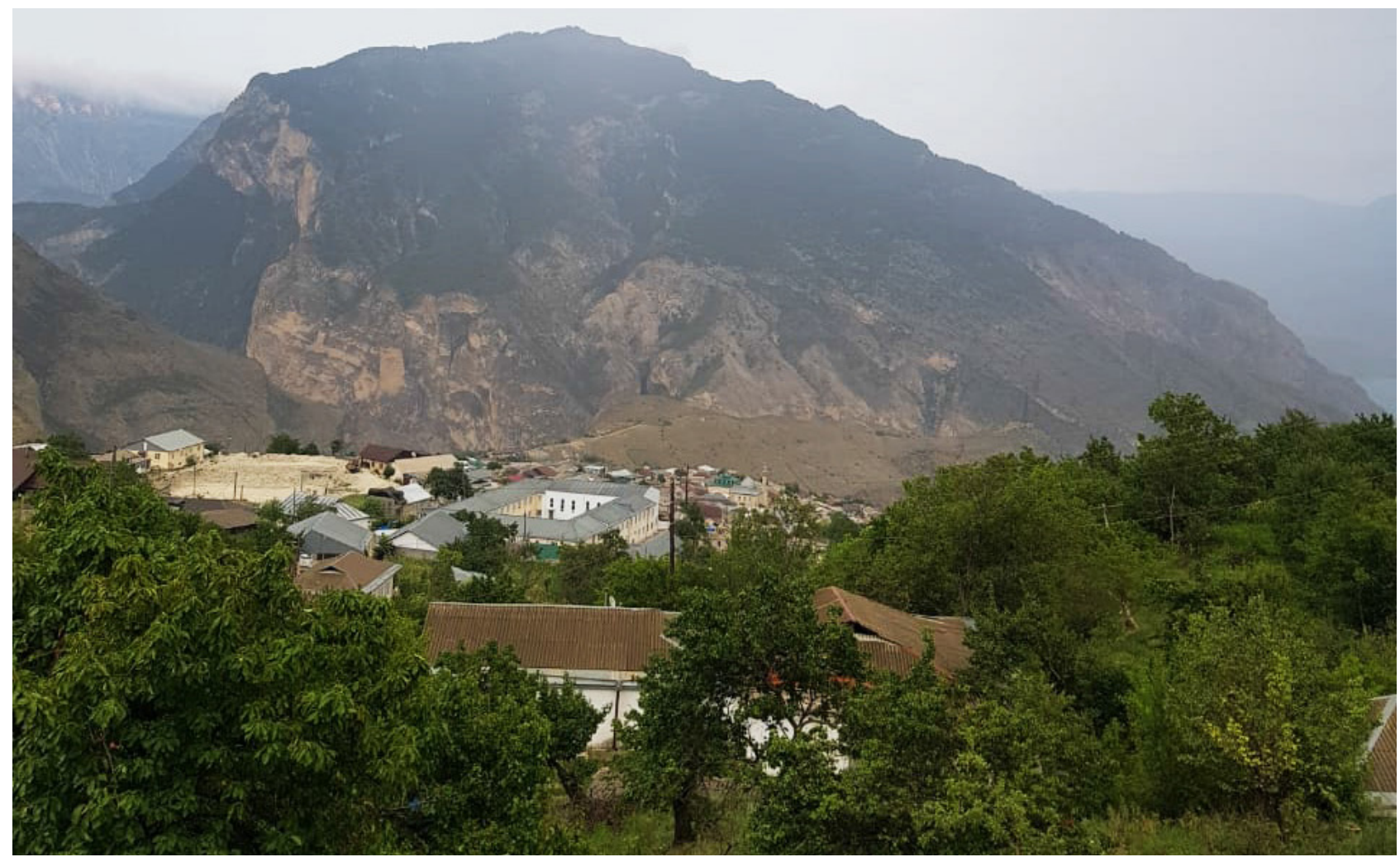

Fig. 11. Untsukul gardens // Gadzhidadaev M. "Untsukul vicinity", 2020

Рис. 11. Унцукульские сады // Гаджидадаев М. «Окрестности Унцукуля», 2020 г.

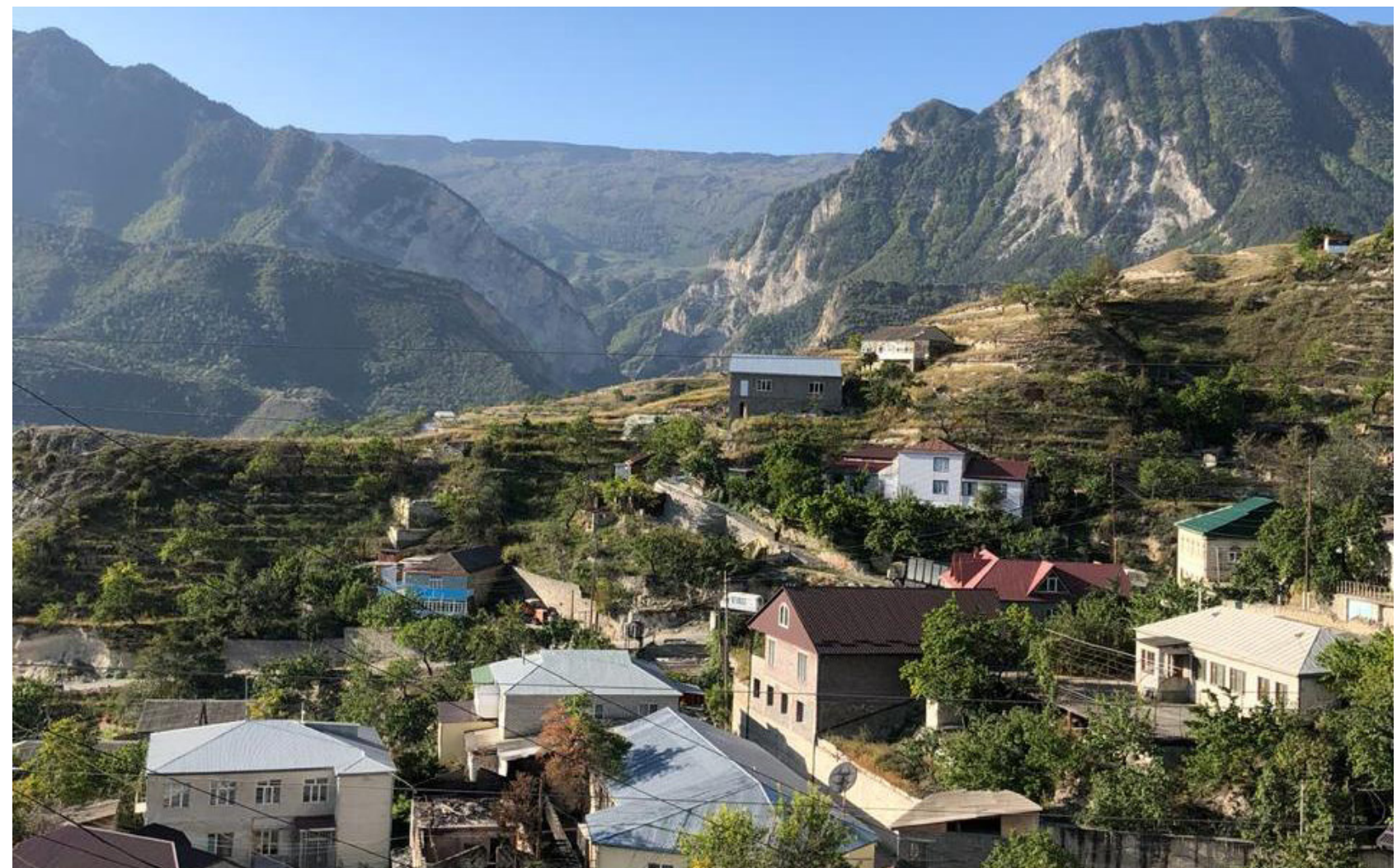

Fig. 12. Untsukul gardens // Gadzhidadaev M. "Untsukul vicinity", 2020

Рис. 12. Унцукульские сады // Гаджидадаев М. «Окрестности Унцукуля», 2020 г. 


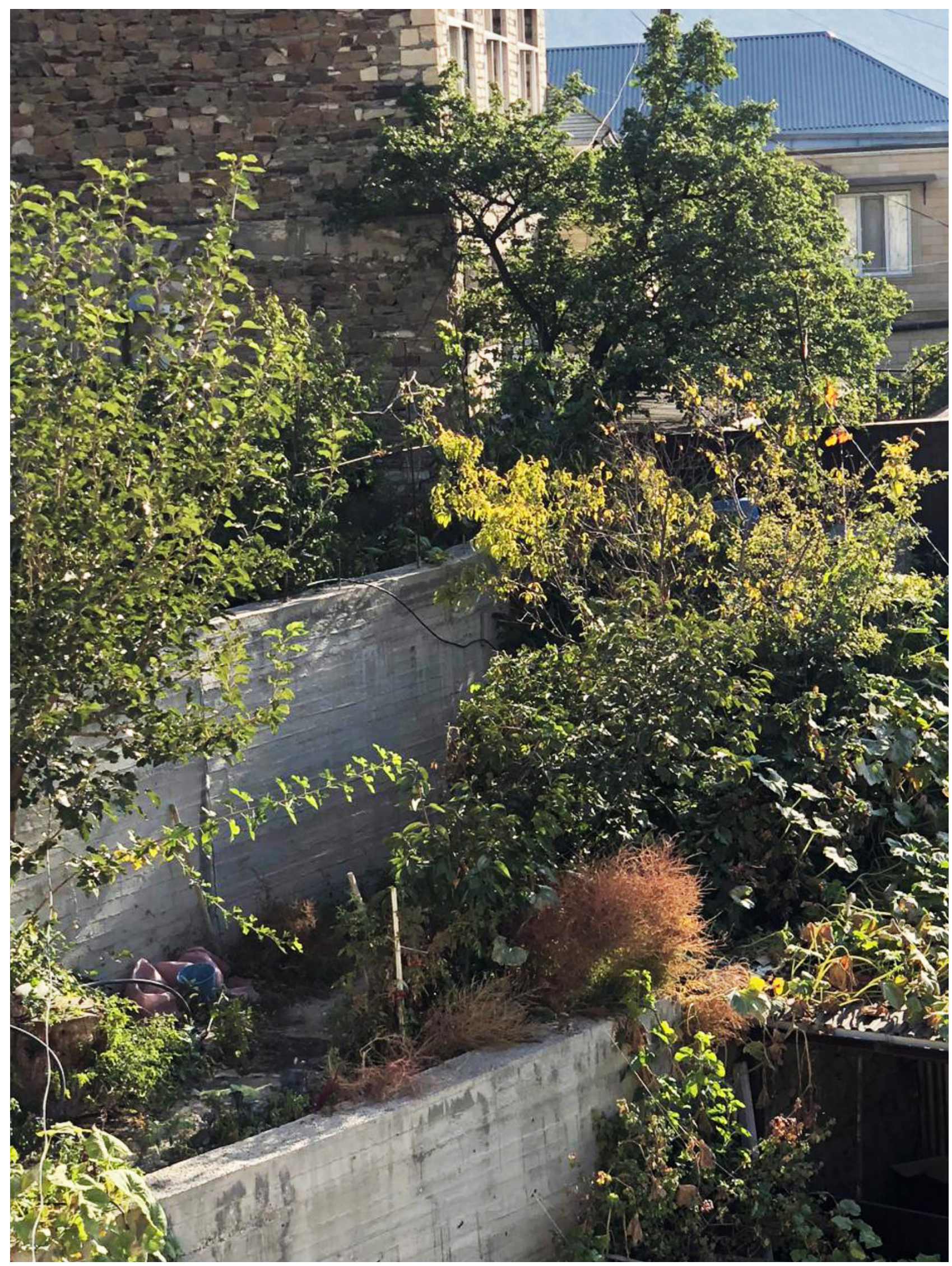

Fig. 13. Modern garden terrace near the house. Untsukul village. Photo by M.K. Musaeva, 2020

Рис. 13. Современная садовая терраса возле дома. Сел. Унцукуль. Фото Мусаевой М.К., 2020 г. 
best local varieties were grafted onto them. In the foothills, gardens and terraces were widely planted. Gardens in Mountain Dagestan were concentrated mainly in river valleys, as well as on terraces [8, p. 145].

Their expertise in the selection made it possible for the highlanders to breed dozens of local varieties of fruits. The old gardens of Dagestan consisted almost entirely of local varieties. Each gardener developed his own methods of tree care and was a breeder in the selection and propagation of varieties adapted to local soil and climatic conditions. Many of them were first cultivated in one area and then transferred to other areas and villages.

There were separate centers for breeding nurseries, and the seedlings were then sold on to other villages. Good fertile areas were chosen for breeding nurseries, they were well prepared and seeds were planted. The nurseries were private, as were the gardens. With good care, the planted seedlings yielded crops in 7 or 8 years. In addition, local gardeners grafted larger wild-growing individual fruit trees located on hay and other field plots.

\section{Preparing for Winter}

Winter preparation of the gardens began immediately after the harvest. Usually, by autumn, the soil was carefully dug manually (i.e. not ploughed). Where there were a need and availability, organic fertilizers were applied. A thorough sanitary cleaning was carried out by pruning dry branches, and from weeds, which were burned. Very often, the trunks of young trees were tied with straw to protect them from being damaged by hares and other rodents. Then they pruned the trees, depending on the species, variety and condition.

In the spring, early watering was carried out, followed by loosening of circles of soil about the roots. Over the summer, five to six more irrigations were carried out, depending on the weather that year. Since early spring, pest and disease control was dealt with. Usually, when pests appeared, manual collection of weevils and other pests was the favored method.

\section{Irrigation System}

The irrigation system of Dagestan, created over many centuries, is characterized by its specific features. These include specific distribution of water for irrigation of the fields of community/ jamaat members. Traditionally, the construction of irrigation facilities and the regulation of the irrigation system was under the strict control of the jamaat. Jamaat established the sequence of irrigation of fields and gardens. It should be noted that in the past, this priority was established once and for all. Then the village foreman and irrigators watched over the correct observance of the order. For the slightest violation of the unwritten provision on watering, the perpetrators were severely punished. According to informants, one bull was taken from the violator of the irrigation order in favour of his community or he was deprived of his place in the queue that immediately led to unenviable consequences. The irrigators also strictly observed the watering. If an irrigator-inspector on his rounds, discovered that, due 
to the carelessness of the owner, water flows out of his garden, then he was deprived of his next turn.

Without the permission of the jamaat, it was forbidden to divert water for other household needs such as the preparation of adobe. In fact, the irrigation system artificially regulated the watering sequence. Since ancient times, fields were divided into sections. The main water canal was a complex engineering structure with supporting stone walls, and water supply tunnels. A special "lock" was used to divert water from the river into the canal. Next, by means of a distributor, water was diverted from the main channel into the middle channels. At one time, P.P. Nadezhdin wrote admiringly of the highlanders' irrigation system: "In Dagestan, the water has been supplied not only into the valleys - I have seen water outlets even high in the

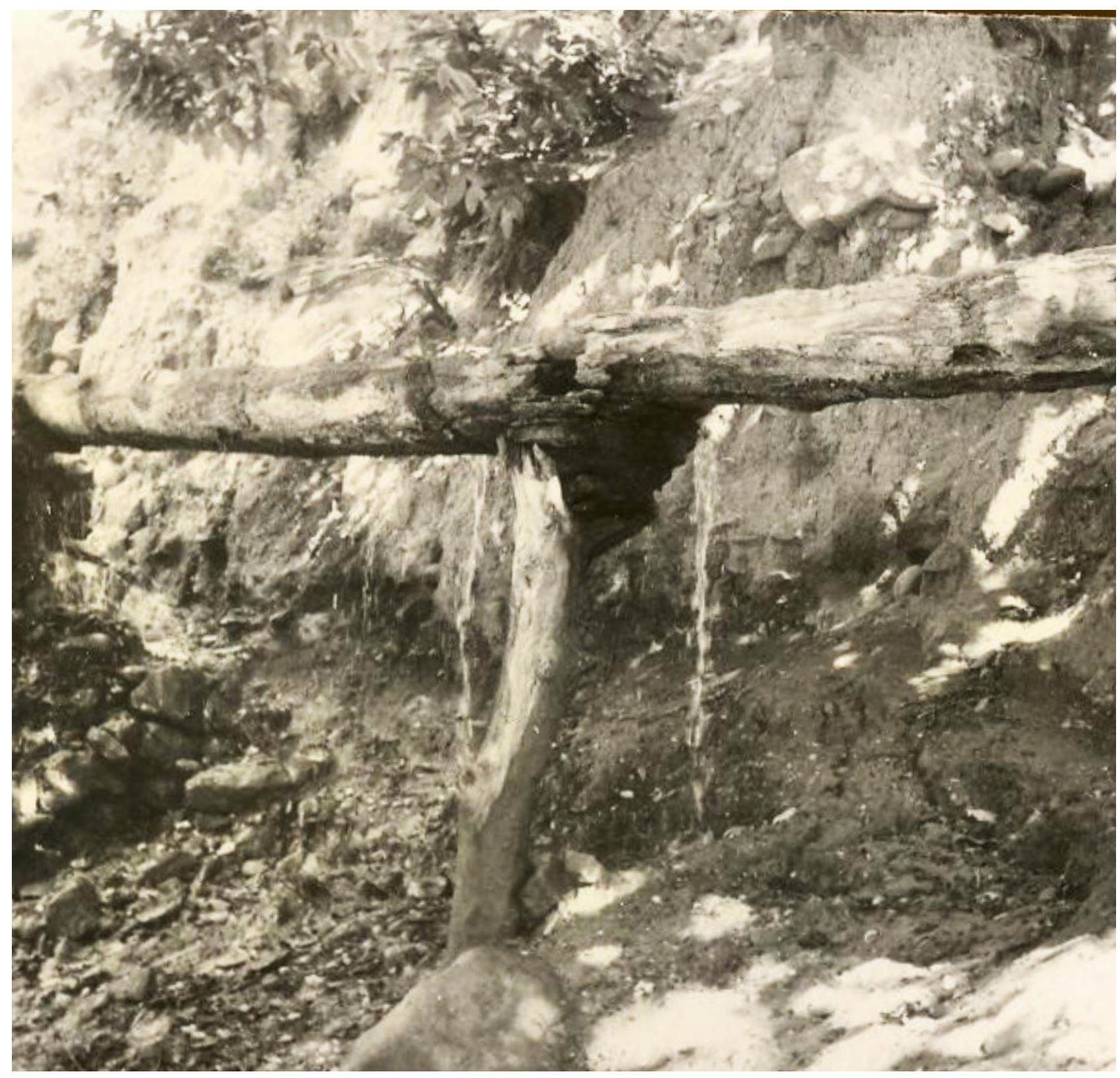

Fig. 14. Wooden aqueducts in gardens. Gimry village. Photo by M.A. Aglarov, 2005

Рис. 14. Деревянные акведуки в садах. Сел. Гимры. Фото М.А. Агларова, 2005 г. 

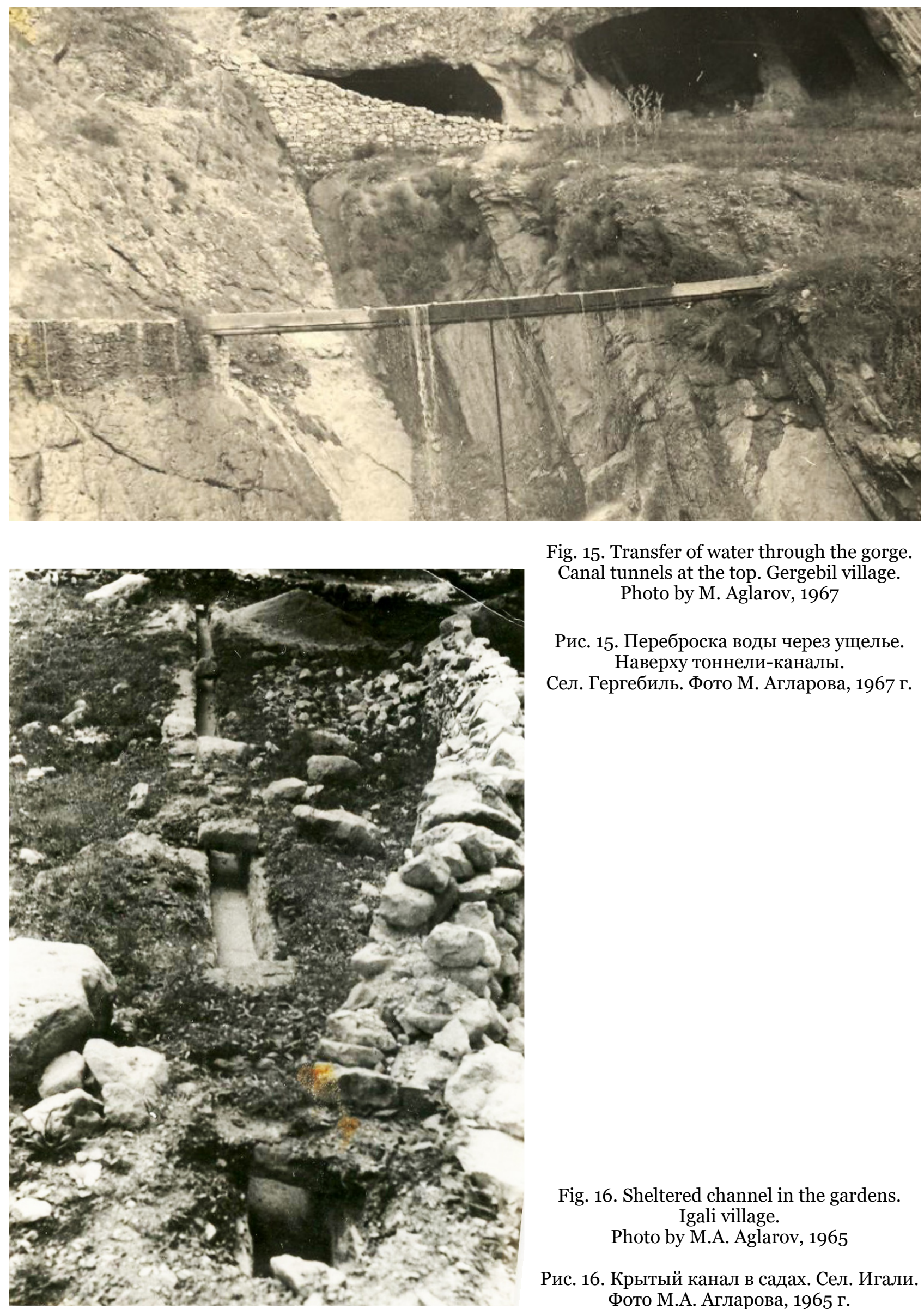

Fig. 15. Transfer of water through the gorge. Canal tunnels at the top. Gergebil village. Photo by M. Aglarov, 1967

Рис. 15. Переброска воды через ущелье. Наверху тоннели-каналы. Сел. Гергебиль. Фото М. Агларова, 1967 г.

Fig. 16. Sheltered channel in the gardens. Igali village.

Photo by M.A. Aglarov, 1965

Рис. 16. Крытый канал в садах. Сел. Игали. Фото М.А. Агларова, 1965 г. 


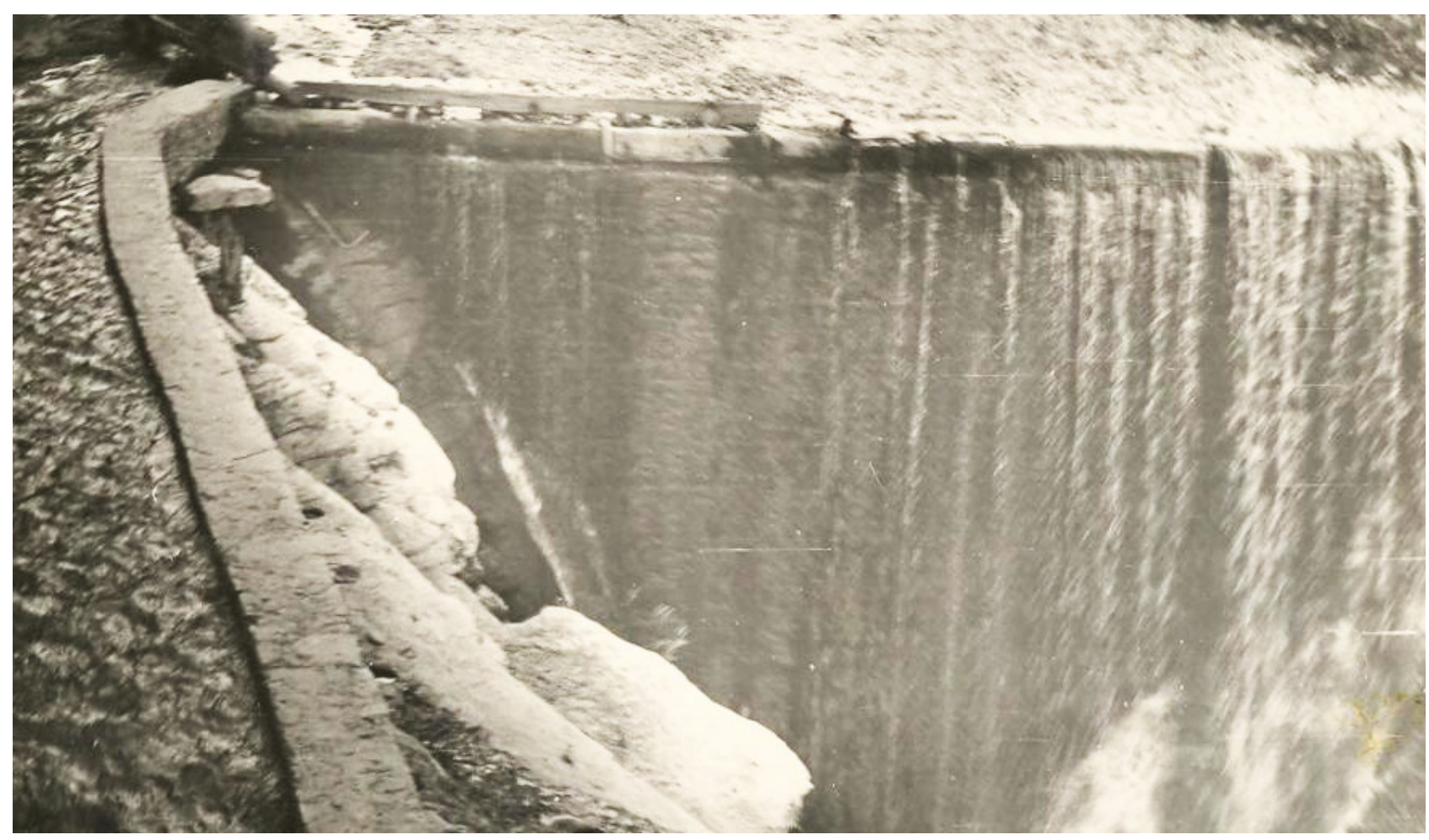

Fig. 17. Dam for water supply to irrigation canals in Stary Chirkei. Photo by M.A. Aglarov, 1965

Рис. 17. Плотина для подачи воды в ирригационные каналы в Старом Чиркее. Фото М.А. Агларова, 1965 г.

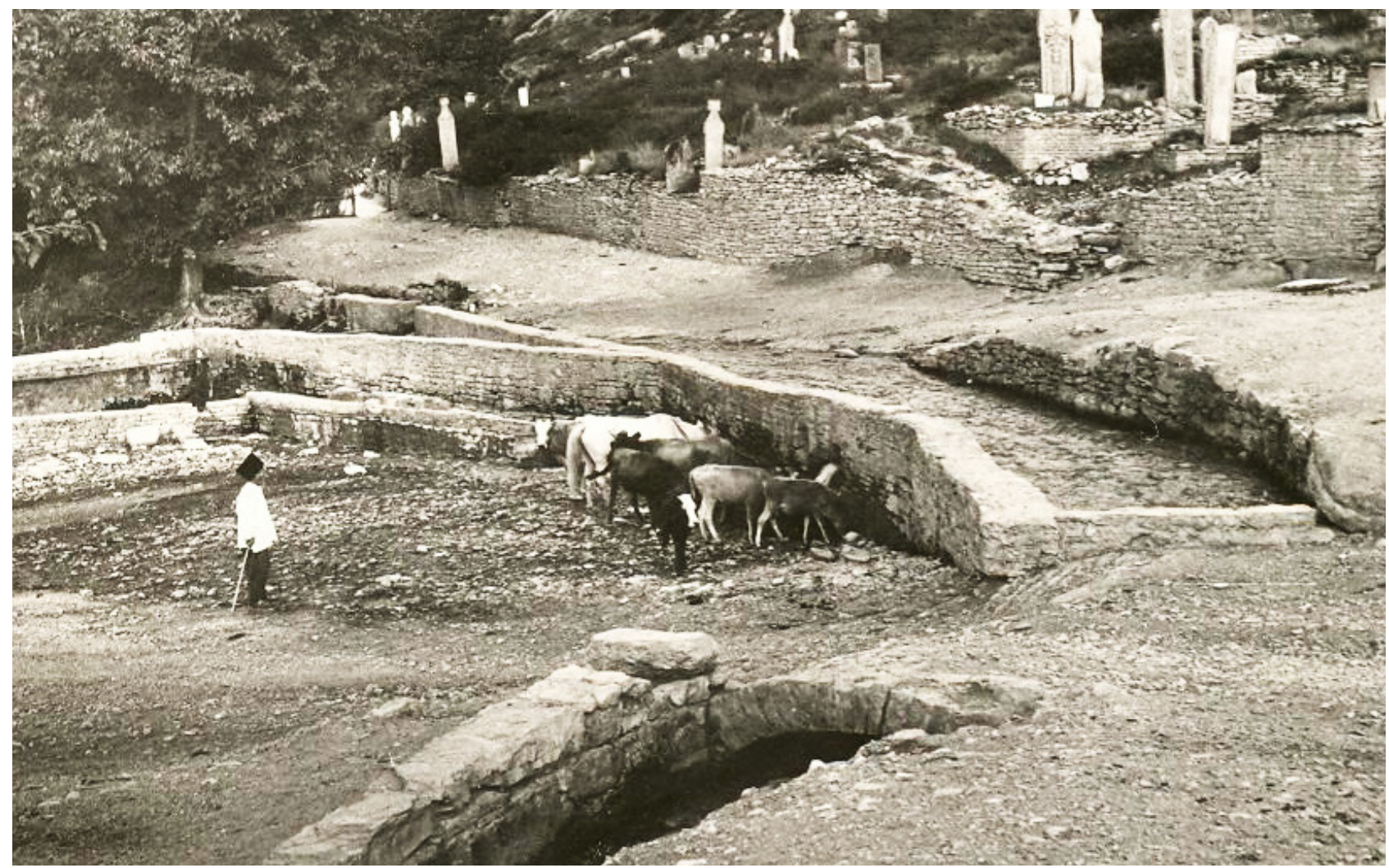

Fig. 18. Water distribution devices. Old Chirkey. Photo by M.A. Aglarov, 1965

Рис. 18. Водораспределительные устройства. Старый Чиркей. Фото М.А. Агларова, 1965 г. 
mountains. Often a native leads water from one height to another, even though a whole gorge, in wooden gutters, almost hanging in the air, on thin and high supports, and sometimes he leads water underground in pipes" [9, p. 63].

All plots belonging to individual farms were located on the top-bottom principle. The first-year watering began from the top and the second from the bottom. This contributed to the observance of the watering sequence between adjacent owners. If irrigation began from the upper section, then the principle of top-bottom irrigation was also observed between the owners of neighbouring plots. This regulation was maintained for all plots. In the event that the owner of the next plot from below did not appear for watering on time, his turn passed to the next one. Even if he came late, he still lost the right to water. Again, the irrigation system itself regulated the sequence of irrigation. When irrigating the terraced areas, the most complex techniques were used, since, with the slightest error, water could flow along the terrace, which threatened the retaining walls. You can often find special pipes in the terraces to drain excess water. Naturally, it was easier to water hayfields, and the even fields, without retaining walls.

In the old days, watering began after the holiday of the First Furrow/ Pervay Borozda. The main channel was kept in top condition. The whole village participated in its repair and cleaning, and the secondary canals were kept in a well-cared-for condition by the owners of the plots through which they passed. Water was considered communal property, the jamaat ruled on the right to water, and private ownership of water in the mountains is still not known. Maintenance of the canals was a communal duty for the entire population, according to the decision of the elders, as announced by their messenger. The construction of walls, aqueducts and their repairs were entrusted to craftsmen. And the rest of the improvised work, like breaking the line and digging the canal, was work for everyone. Those who avoided repair work were fined according to tariffs adopted by each jamaat. Absence from the village during the renovation was not allowed. If someone needed to leave, he had to provide someone who would do his job.

The irrigators monitored the health of the main and secondary channels. All preparatory work for cleaning and repairing the irrigation system was carried out before the water was turned on. The mountaineers did not have special tools for digging, clearing and processing canals - they mainly used ordinary picks, crowbars, shovels, and hand carts. Accordingly, as necessary, the whole jamaat also built a few reservoirs. The current state of the traditional irrigation systems is that they are largely neglected, and replaced by spraying.

\section{Fresh and Canned Fruit Slump After 1917}

Fresh fruits, apricot pits (kernels), and walnuts were also exported to the Russian market. In 1916, canneries in Dagestan put on the market about 4800 tons of canned fruits, which amounted to approximately $15 \%$ of the total Russian Empire production. During the Civil War (1918-1921) due to the impossibility of acquiring sugar and the absence of sales outside of Dagestan, the factories were impoverished and by the time of the establishment of Soviet Power in 1920, they were in a dilapidated state. In 
1921 all ten factories only produced 193,3 tons of canned fruits, that was 25 times less compared with 1916 [10, p. 45].

In 1921, the industry of Dagestan was producing 10 times less than in 1913. Most of the cities were destroyed and ruined - Khasavyurt was completely destroyed, Derbent - three quarters, Kizlyar - half, Port-Petrovsk (now Makhachkala) and Temir-KhanShura (now Buinaksk) - by one third. Less than half of the 48 fisheries that were the main industry in Dagestan remained. Fish production fell 40\% from pre-war levels [11, p. 145].

Handicraft production, which also fed many thousands of mountain families, fell sharply. Due to the narrowing of the basic raw materials and sales markets, the value of its production decreased from 6.4 million to 1.2 million roubles from 1915 to 1923 as the number of artisans decreased from 132.5 thousand to 46 thousand. Agriculture was in an even worse position. The number of working livestock in comparison with 1913 decreased by $60-75 \%$, the sown area decreased by $54 \%$. Bread in the republic was produced 12 times less than necessary. In 1922, there were 200 thousand hungry people here [11, p. 145-146].

\section{Soviet Recovery}

In Soviet times, radical changes took place in the organization of gardening in Dagestan. The first major step was the opening of the Dagestan experimental fruitgrowing station in Buinaksk at the beginning of 1931, which studied and developed gardening in the republic.

Basically, the mountainous region remained the centre of horticultural culture in the 1930s. In addition, fruit trees were planted in the highland regions. As before, the largest number of fruit trees (46.1\%) were planted in mountainous regions. In southern Dagestan, orchards accounted for $33.3 \%$, in the foothills of the republic $17.6 \%$, in the northern plains $2.4 \%$ and in the alpine regions $1.3 \%$ [6, p. 121-122].

\section{Artificial Terracing and Soviet Technology}

As in the past, the terraced system of planting gardens prevailed in mountainous areas, associated with the relief of the mountains that meant there was a general lack of land that could be ploughed. Natural terraces for planting gardens were widespread in all-mountain zones, but as a rule, there were not enough. In the alpine part, the gardens were laid out exclusively on artificial terraces. Most of the opportunities to build gardens on natural terraces were in the foothills. These natural terraces, located compactly near the villages, were systematically fertilized and irrigated as required.

Gardens in the 1930s mainly grew local varieties. The Fruit Experimental Station had 70 varieties of apple, up to 30 varieties of pear, over 40 varieties of apricot, and over 30 varieties of peach. For example, in the 1950s, the village of Khadzhalmakhi handed over to the state more than 1.5 thousand tons of apricots and 2-3 thousand tons of apples and pears in a regular harvest year. There were local varieties of pears in the gardens, which produced 2-3 tons per tree. Nowadays there are almost no such trees left, and the harvests are estimated at a few hundred tons [12, p. 200]. 
In the years before WW2, there were 21 canneries operating in the republic. In 1939, 5.5 million conventional cans of fruit (capacity 353.4 cubic centimetres i.e. 1/3 litre) were produced.

The period from 1946 to 1950 witnessed the radical restructuring of the horticulture of the republic, through an urgent speedy reconstruction of old unsystematic gardens. Old trees were uprooted, replaced by young trees, introducing more promising varieties.

The area of commercial market gardens increased especially from 1954 to 1956 when over 13 thousand hectares of new market gardens were planted by collective state farms (Kolkhoz). To complement this, fruit processing also increased dramatically. The annual output of canned goods amounted to 100 million conventional fruit cans. For example, in the Tsudakhar, Botlikh, Kaitag, Gergebil, Kasumkent, Uitsukul, Akhtynsky and other areas, the sale of horticultural produce accounted for $70 \%$ to $80 \%$ of total income.

In the 1980 s, the area under horticultural cultivation amounted to 65.5 thousand hectares or $1.6 \%$ of the agricultural land of Dagestan. This land provided production of over 6 per cent of gross agricultural output and 16\% of crop production of Dagestan.

The industrial upsurge gave a powerful impetus to the development of processing enterprises in areas with well-developed horticulture. Thanks to the development of a relatively efficient canning industry it became possible to solve many socio-economic problems in the countryside, especially employment more than 30 thousand people. Horticulture reached its highest level of development in 1989 when 149.0 thousand tons of fruits were produced.

\section{Kolkhoz Collapse of 1990}

With the collapse of the collective and state farm systems, in which all economic activity was planned, with harvest quotas and harvest plan, collective care of the gardens was discontinued. For some reason, unlike most state enterprises, gardens were left without "new" private owners and came to a neglected state. Abandoned orchards became unproductive, and yields became extremely low. From the 1960s in the mountainous and foothill areas of Dagestan, especially after the liquidation of the farm system, many lands were banned from habitation by families, because they were too far from kolkhoz settlements, so manual labour was all that was available and mechanization was abandoned.

The mechanization of horticultural production processes in Dagestan was solved much more slowly than in other industries. Heavy labour mechanization processes in horticulture were hampered by the lack of machines that could be used in terraced gardens. In Russia, as a whole so-called "small mechanization" was not to be found in farms. Special horticulture machines had increased significantly but were of little use in mountain horticulture. In the decay, many old gardens were uprooted.

The decay was in spite of climatic and natural conditions that made it possible to grow high yields of a wide variety of fruits of good quality on large areas at a low 
cost. In the past, they did not just exploit nature but had long been familiar with, for example, the art of grafting, without which cultural gardening is unthinkable, as passed down from generation to generation.

\section{Degradation of Horticultural Land}

However, over the past 30 years, the area of garden land, especially in the mountains, has been decreasing, despite the technology of gardening remaining extensive. More than 20 years ago, the Dagestan ethnographer Magomedzagir Osmanov wrote regretting this tendency: "Earlier, the mountaineer never created a plot without making it a productive area. He was already planting a tree in order to "catch on" to the slope, gradually levelling it. But, by the end of 1980 os in the mountains, 6 thousand hectares of ready-made garden land was empty, not to mention the slopes that could be turned into excellent garden plots" [12, p. 149].

Explaining the deep social causes of the degradation of the traditional agriculture of the Dagestanis, Professor Mamaykhan Aglarov wrote that "private traders still felt that gardens were not only of economic benefits for them but also for their ecology. A thousand-year hereditary occupation in gardening is their peculiar religion. Accordingly, the order and aesthetics of the garden were observed in the private sector" that the alienation of the garden economy from the owners and the creation of large horticultural collective farms led to the degradation of the horticultural culture. "The introduction of agrotechnical achievements proceeded in the order of the reconstruction of gardens according to methods developed not in Dagestan conditions". It was clear that the intensification of the economic and horticultural culture is not the same thing, that "the modernization of agriculture was inevitable, but it had to be introduced gradually, modified by a comprehensive scientific and practical rationale" [13, p. 31].

\section{A brief overview of the definitions}

To paraphrase P. M. Bauer, anthropologist and since the early 2000 s a leading advocate of re-wilding: ...Understanding the differences between horticulture and agriculture can be confusing because some agricultural strategies cross over into horticultural strategies. The word agriculture is derived from the Latin ager (field) and culture (culture/cultivation). Horticulture derives from the Latin Hortus (garden) and culture. Cultivating a field is different from cultivating a garden. The implications of agriculture's mono-cropping primary succession plant obsession are evident its very origin. In contrast horticulture's diversity of plants and smallerscale style is also a result of its origins.

Agriculture exploits transplanting, seeding, tilling, burning, pruning, fertilizing, selective harvesting, crop-rotation, etc. But the main difference between agriculture and horticulture involves agriculture's focus on using these tools to create one habitat; the mono-crop meadow or "field." Horticulture uses the same strategies of cultivation to promote ecological succession and bio-diversity of landscapes 
- the garden of forest succession. Thus, the term "sustainable agriculture" is an oxymoron ${ }^{1}$.

A complementary view is given by NC State University, Horticultural Science University. Perhaps, you see horticulture as small-scale, like gardening, and see agriculture as large-scale, like farming. Generally speaking, this assumption is somewhat true, but greater differences exist. Horticulture can be classified as a field under the umbrella of agricultural science. That being said, they both use many of the same techniques for crop cultivation and overlap with crop and turf sciences.

Horticulturalscienceincludesthe research, study and practice of plantcultivation, plant propagation, plant breeding, production of crops and plant physiology. The plants focused on are mainly vegetables, trees, flowers, turf, shrubs, fruits and nuts. The key difference is that horticultural products have to both look good and taste good! For example, if you are enjoying a fresh, juicy tomato on a sandwich-a horticulturist grew it. If you are dipping French fries into ketchup, a crop science graduate running an agricultural farm grew it $^{2}$.

David Rae, emeritus director of horticulture at Royal Botanic Garden Edinburgh, defined Gardening and Horticulture in Horticulture: Plants for people and places (pp. 1307-1338) December 2013, Springer: Gardening and horticulture are both activities concerned with the cultivation of plants. While there is much overlap between the two activities, the former refers to a leisure activity practiced by home or hobbyist gardeners, while the second refers to a scientifically underpinned, and highly specialized, professional occupation. .... Different types of cultivation, such as organic gardening, are used to highlight the differences in approach between gardening and horticulture, while garden styles or practices such as patio gardening or small allotments (provided free by the municipality in the UK) gardening are used to show that while gardeners are the consumers of products and services, professional horticulturists are not only providers of the products and services, but have also developed the technology to make the style or practice possible [14].

\section{Prospects}

Market conditions are inefficient. Horticulture in the republic encounters difficulties in selling its products, which are either sold below cost or not sold at all. For example, in 2019, apricots fetched 5 roubles each at the Tlokh canning factory, and 6 roubles at the Gotsatlinsky cannery.

To address issues ensuring the restoration and further development of horticulture in the Republic of Dagestan, the republican target program "Development of gardening in the Republic of Dagestan" for 2011-2016 was adopted. It will be very

1 Horticulture vs. Agriculture, 28 February 2008, Peter Michael Bauer https://www.petermichaelbauer. com/horticulture-vs-agriculture/

2 Agricultural Science and Horticulture, 23 January 2017, NC State Horticulture Science, NC State University https://horticulture.cals.ncsu.edu/online/horticulture-vs-agriculture/ 
frustrating if, as seems likely, the centuries-old traditional experience of mountainvalley management remains dormant, and yet is ironically a key source of knowledge about the environment.

Summarizing, it should be noted that the transformation of horticulture as a subsystem of life support in the mountain enclaves of Europe, the Caucasus and Dagestan requires a monographic, comparative historical study, using the achievements in this area in Russian and world science.

Acknowledgement: The study was supported by the Russian Foundation for Basic Research (RFBR) within the framework of the RFBR projects 19-09-00490 A "The use of ethno-cultural traditions in the strategy of social, economic and environmental development of the mountain territories of Dagestan" and 19-2905205 "Anthropogenic soil agricultural terraces of the Caucasus".

Благодарность: Исследование выполнено при финансовой поддержке Российского фонда фундаментальных исследований в рамках проектов РФФИ 19- 09-00490 А «Использование этнокультурных традиций в стратегии социально-экономического и экологического развития горных территорий Дагестана» и 19-29-05205 «Антропогенные почвы земледельческих террас Кавказа».

\section{REFERENCES}

1. Aglarov MA. Once again on agricultural terraces of Dagestan [Eshhe raz o zemledel 'cheskix terrasax Dagestana] Herald of the Daghestan Scientific Center [Vestnik Dagestanskogo nauchnogo centra RAN]. 2016;62: 30-53.

2. Aliev BG. Unions of rural communities in Dagestan in the 18th - first half of the 19th centuries (Economics, land and social relations, administrative structure) [Soyuzy Sel'skikh obshchin Dagestana $v 18$ - pervoy polovine $19 v$. (Ekonomika, zemel'nyye $i$ sotsial'nyye otnosheniya, struktura vlasti)]. Makhachkala: IHAE DSC RAS, 1999.

3. Aliev BG. Agriculture and land tenure in late feudal Dagestan [Zemledeliye i zemlevladeniye $v$ pozdnefeodal'nom Dagestane]. Makhachkala: ALEF, 2014.

4. Monuments of customary law in Dagestan in the 17th - 19th centuries. Archive materials. Compilation, preface and notes by H.M. Khashaeva [Pamyatniki obychnogo prava Dagestana XVII-XIX vv. Arkhivnyye materialy. Sost., predisl. i prim. KH.-M. Xashaeva]. Moscow: Nauka, 1965.

\section{СПИСОК ЛИТЕРАТУРЫ}

1. Агларов M.А. Еще раз о земледельческих террасах Дагестана // Вестник Дагестанского научного центра РАН. 2016. № 62. С. 30-53.

2. Алиев Б.Г. Союзы Сельских общин Дагестана в XVII - первой половине XIX в. (Экономика, земельные и социальные отношения, структура власти). Махачкала: ИИАЭ ДНЦ РАН, 1999.- 339 с.

3. Алиев Б.Г. Земледелие и землевладение в позднефеодальном Дагестане. Махачкала: АЛЕФ, 2014. - 540 с.

4. Памятники обычного права Дагестана XVII-XIX вв. Архивные материалы. Сост., предисл. и прим. Х.-М. Хашаева. М.: Наука, 1965. - 28 о с.

5. Яхъяев М.М. Экономическая эффективность горно-долинного садоводства Дагестана. Махачкала, 1974. - 78 с.

6. Сельское хозяйство Дагестана. Москва; Ленинград. Изд-во АН СССР. 1946.- 334 с.

7. История Дагестана. Т.1. М.: Наука, 1967. $-433 \mathrm{c}$.

8. Магомедова П.М., Мусаева М.К. Горно-долинное садоводство в Дагестане: 
5. Yakhyaev MM. Economic efficiency of mountain-valley gardening in Dagestan [Ekonomicheskaya effektivnost ' gorno-dolinnogo sadovodstva Dagestana]. Makhachkala, 1974.

6. Agriculture of Dagestan [Sel `skoe xozyajstvo Dagestana]. AN SSSR Press. Moscow, 1946.

7. History of Dagestan [Istoriya Dagestana]. Vol. 1. Moscow: Nauka, 1967.

8. Magomedova PM., Musaeva MK. Mountain-valley horticulture in Dagestan: issues of preserving folk traditions of householding [Gorno-dolinnoye sadovodstvo v Dagestane: problema sokhraneniya narodnykh traditsiy khozyaystvovaniya] Proceedings of the 3rd Interntaional Congress of Caucasiologists. Tbilisi: I. Ivane Javakhishvili Tbilisi State University, 2013: 415-416.

9. Nadezhdin PP. Caucasian region. Nature and people [Kavkazskij kraj. Priroda i lyudi]. Second edition. Tula, 1895.

10. Dagestan industry in five years [Dagestanskaya promy `shlennost` za pyat` let. 1920-1925]. Buinaksk, 1925.

11. History of Dagestan [Istoriya Dagestana]. Vol. 3. Moscow: Nauka, 1968.

12. Osmanov M-ZO. Economic and cultural types (areas) of Dagestan in the Soviet era: patterns of development and transformation, the extinction of traditional forms [Xozyajstvenno-kul 'turny 'e tipy ' (arealy ') Dagestana $v$ sovetskuyu e 'poxu: zakonomernosti razvitiya i transformacii, vy 'my 'vanie tradicionny‘x form]. Moscow: Nauka, 2002.

13. Aglarov MA. Hindalal. Avars of the Mountain valleys of Central and Western Dagestan. Studies on traditional culture and ethno-economics. [Xindalal. Avarcy gorny 'x dolin Central `nogo i Zapadnogo Dagestana. Ocherki tradicionnoj kul 'tury ` $i$ e 'tnoe `konomiki]. Maxachkala: Mavraev, 2018.

14. David Rae. Gardening and Horticulture Horticulture: Plants for people and places. Volume 1. Production Horticulture. December 2014, Springer: Dordrecht Heidelberg New York London, pp.1307-1338. проблема сохранения народных традиций хозяйствования // Материалы 3-го Международного Конгресса Кавказоведов. Тбилиси: Тбилисский государственный университет им. Ивана Джавахишвили, 2013. C. $415-416$.

9. Надеждин П.П. Кавказский край. Природа и люди. Второе издание. Тула, 1895. $449 \mathrm{c}$.

10. Дагестанская промышленность за пять лет. 1920-1925. Буйнакск, 1925. - 237 с.

11. История Дагестана. Т. 3. М.: Наука, 1968. - $426 \mathrm{c}$.

12. Османов М.-З.О. Хозяйственно-культурные типы (ареалы) Дагестана в советскую эпоху: закономерности развития и трансформации, вымывание традиционных форм. М.: Наука, 2002. - 222 с.

13. Агларов М.А. Хиндалал. Аварцы горных долин Центрального и Западного Дагестана. Очерки традиционной культуры и этноэкономики. Махачкала: МавраевЂ, 2018. $-152 \mathrm{c}$.

14. David Rae. Gardening and Horticulture. In: Horticulture: Plants for people and places. Volume 1. Production Horticulture. December 2014, Springer: Dordrecht Heidelberg New York London, pp.1307-1338.

Статья поступила в редакцию 14.09.2020 г. 